\title{
Partisan political connections, ethnic tribalism, and firm performance
}

\author{
Vincent Tawiah ${ }^{1} \cdot$ Abdulrasheed Zakari $^{2} \cdot$ Yan Wang $^{3}$ (D)
}

Accepted: 7 November 2021 / Published online: 27 November 2021

(c) The Author(s) 2021

\begin{abstract}
This paper investigates the impact of partisan political connections and ethnic tribalism on firm performance in a hyper-partisan political environment. Although existing literature generally shows that political connections improve firm performance, we argue that under the theory of electoral competition, political connections can be a double-edged sword because of the tension of partisan politics. Hence, we expect that changes in government can affect firm performance. Using a unique dataset from Nigeria, we find that political connections are valuable when a firm's patron party is in power, whereas they are detrimental to firm value when their patron party is in opposition. Furthermore, we find that CEO ethnic tribal affiliation with the President improves firm performance even when the firm's patron party is in opposition. This paper extends the literature on political connections and helps managers and policymakers understand the timely use of political connections in a hyper-partisan environment.
\end{abstract}

Keywords Partisan politics $\cdot$ Political connections $\cdot$ Tribalism $\cdot$ Firm performance

JEL Classification $\mathrm{G} 30 \cdot \mathrm{G} 32 \cdot \mathrm{G} 34 \cdot \mathrm{G} 38$

\section{Introduction}

Building political ties are almost inevitable for the continued survival of companies in developing countries because of the power and control politicians have on scarce resources. However, political connections can be a double-edged sword, especially in a highly corrupt and hyper-partisan political environment (Shleifer and Robert 1994; Faccio 2006; Leuz and Oberholzer-Gee 2006; Ang et al. 2013; Chen et al. 2017; Belghitar et al. 2019). On the one hand, political connections with a party in government give firms easier access to loans,

Yan Wang

yan.wang@ntu.ac.uk

1 DCU Business School, Dublin City University, Dublin, Ireland

2 School of Management and Economics, Center for Energy and Environmental Policy Research, Beijing Institute of Technology, Beijing, China

3 Department of Accounting and Finance, Nottingham Business School, Nottingham Trent University, Nottingham, UK 
tax avoidance, and high-profile publicity. On the other hand, firm performance can be jeopardized due to elimination strategy and restriction to vital resources if the firm is connected to a political party that is in opposition at the time.

Despite the contrasting arguments for political connections and firm value/performance, existing literature has generally concluded that political connections have a positive impact on firm performance without considering the partisan affiliation of the firms. We argue that the partisan affiliation and the effect of political connections in developing countries with a high partisan political environment are worth exploring for the following reasons. First, in developing countries, resources are predominately owned and controlled by people who have political power. Hence, business transactions are not about the quality of the firm involved but designed around people who hold power to influence. This is even worse in countries with a high level of corruption where everything can be done outside the law. Second, due to the dominance of government involvement in the economy, the private sector is weak; hence, the government is the major consumer in the market (Deloitte 2014). As such, government business and contracts provide more revenue to firms than revenue from individual consumers. Even foreign contracts and development programs are awarded to firms through the incumbent government. Third, a political party is a team of politicians whose primary goal is to win electoral office (Bawn et al. 2012). By virtue of their description, politicians are very competitive and even willing to do anything to stay in electoral office, including sabotaging the performance of firms associated with the opposition party. This vote-seeking behaviour of political parties is well enshrined in Downs's (1957) theory of electoral competition. Not only does the party in government have power and control over resources, but most deals and contracts are also awarded with political motives.

In a highly partisan political environment, the party in power uses all means to threaten the survival of the opposition party. This includes but is not limited to negatively impacting businesses that support or align themselves with the opposition party. Some of the common strategies are: terminating contracts prematurely, delaying payment to the firm, unnecessary probing into firms' activities, and restricting access to foreign currency and foreign contracts. Anecdotal evidence suggests that under the terms of the People's Democratic Party (PDP) of Nigeria in government, they restricted the issue of foreign currency for importing firms that did not have a significant connection to PDP. Such actions of weakening the opposition party can have a negative influence on firms that support the opposition party. Leuz and Oberholzer-Gee (2006) find that it is more difficult for firms to build connections with the government when their patron party falls from power. Hence, these firms aligned with the opposition party underperform. The combining effect of these unique characteristics of developing countries suggests that the performance of politically connected firms (PCC) is likely to vary dramatically over time, depending on the political fortunes of its patron party, making such connections riskier.

Due to the dominance of tribalism in developing countries, we extend the existing literature by considering the impact of ethnic tribalism on partisan politics and firm performance in Nigeria. Juma (2012) argues that leaders of political parties focused on pursuing tribal interests. Even in the era of democracies, many African countries have reverted to tribal identities as foundations for political competition. Hence the significance of tribal connection cannot be underrated, especially in the political environment of most African countries. We argue that the tribal factor is one of the principal variables that often define political contestations in most electoral democracies, especially in Nigeria. More often than not, the ethnic tribes connected to the political party in government get a soft landing in making business decisions through loans, licenses, contracts, and tax holidays. The corruption level, economic significance, ethnic tribalism, and partisan political environment 
make Nigeria a suitable setting for investigating the impact of partisan politics on firm performance. Prior literature asserts that political connections are more valuable in highly corrupt countries. Nigeria is among the most corrupt countries, scoring 27/100 in the 2018 corruption index (Transparency International 2019). The 2018 Best Countries Rankings from U.S. News and World Report similarly rates Nigeria as the most corrupt country in the world. Although Nigeria is a highly corrupt country, it is the biggest and fastest growing economy within the Sub-Saharan Africa region. According to the 2018 U.S. News and World Report, Nigeria is one of the top four African countries for engaging in business, number one for entrepreneurship, and ranked among the top four for movers (up and coming economies) in Sub-Sahara. It is the biggest middle-income consumer market in Africa (AfDB 2019) and is the second country with more successful domestically owned listed firms. According to PWC Nigerian economic outlook, Nigeria is recovering at a faster rate after negative growth in 2016.

Ideally, political parties are prerequisites for modern elections and are established to create a competitive ideology, which is vital for democracy and development (Ujo 2001). However, Balewa (1994) argues that the role of partisan politics is not fully understood in most African countries like Nigeria in particular. Hence, partisan politics frustrates development and growth. In a bid to gain power, political parties do everything possible to their opponent, regardless of the rule of law. This is especially true as partisan politics is seen as a source of division in a country. Ezeani and Agudiegwu (2015) claim that even religion and ethnicity are clustered around political parties. For example, PDP is known to be for Christians and people from the South while All Progressive Congress (APC) is for Muslims and people from the North.

Our results show that approximately $60 \%$ of the listed firms in Nigeria have political connections mostly with either PDP or APC, which are the two main parties that have ruled the country since 1999. As expected, we find that more firms are connected with PDP because it has been in government for a long time. However, there have been increasing connections with APC after its first federal election victory in 2015. Our results provide empirical evidence that partisan political connections are valuable only when the patron party is in government. Specifically, firms underperform when their connected political party is in opposition. Our results also indicate that having people from different political parties provide continuous positive value even when there is a change of government. Regarding the impact of tribalism, we find that firms that are politically connected to the opposition party but have an ethnic tribal connection with the President through the CEO did not experience negative performance as compared to similar firms affiliated to the opposition party without ethnic tribal connections to the President. Our results are robust to alternative measures of political connections and firm performance. We also employ unbalanced panel data, two-stage least square (2SLS), the system generalized method of movements (GMM), and difference-in-differences (DID) to ensure our findings do not suffer from self-selection bias, unobserved heterogeneity, and potential endogeneity issues.

This paper seeks to extend and make a number of new contributions to the existing literature on political connections and firm performance. First, compared with the extant literature, this paper considers an important factor (the partisan affiliation of the firms) that has been overlooked in prior literature and provides an understanding of why mixed results have been found in the existing literature. Our results show that political connections can have both positive and negative impacts on firm performance, depending on the timing and the status of its patron political party. To the best of our knowledge, our results provide the first empirical evidence that supports the double-edged argument on political connections. Second, our analysis illustrates why it is vital for firms to engage people from both sides of 
the political spectrum to better harness the benefits of political connections. Practically, our results are consistent with Dangote Cement Limited's political strategy of aligning with both APC and PDP when each party gains power. If knowing that the damage from losing political connections sometimes is inevitable, it is vital to explore what could be done to protect firm value. We provide empirical evidence on how firms that are in opposition could minimize their damage by appointing a CEO whose tribal affiliation is the same as that of the President. Third, this paper is one of the few studies, if not the only study, that has extended the literature on political connections into partisan politics and specifically within the African setting. The corruption level, economic significance, ethnic tribalism, and partisan political environment make Nigeria a suitable setting for investigating the impact of partisan politics on firm performance. By doing this, we have provided evidence that supports the claim that countries with multiple parties' democracy do not fully understand partisan politics can be harmful (Belwa 1994).

The remainder of the paper is structured as follows: Sect. 2 introduces the politics and tribalism in Nigeria. Section 3 reviews the literature and develops hypotheses. Section 4 presents the research design. Section 5 presents and discusses our main results as well as robustness test results. Section 6 concludes the paper.

\section{Politics and tribalism in Nigeria}

Nigeria, Africa's most populous and oil-rich nation, is one of the most influential countries on the continent. Nigeria gained independence from Britain in 1960 and later became a republic in 1963. Democratic elections, coups, and counter-coups characterize the postindependent history of Nigeria up until 1999 (Hanson 2017). Nigeria has had six successful presidential and parliamentary elections since the fourth republic (1999-2019). These elections have been contested by different political parties but dominated by PDP and APC (Omodia 2010). The PDP was formed in 1997, has ruled for 16 years, and has had impacts on business activities. For instance, it is widely believed that PDP is connected to major businesses (Zenon Petroleum and Gas Ltd; and Global Fleet Group), and it has given them a soft landing in operating their business when PDP was in government. The PDP government offered a ten-year tax holiday to Dangote cement factories in 2007, making Dangote Cement Ltd the number one cement producer in Nigeria with over $65 \%$ market share (Adesunkanmi 2014).

The APC was formed through the alliance of Nigeria's three biggest opposition parties and came into power in 2015. The APC government introduced the Presidential Enabling Business Environment Council (PEBEC) in August 2016 (Channel T.V. 2018), which gives the President the power to award contracts to anybody of choice. This implies that governments can easily award contracts to firms that are connected with them. For example, the APC government has awarded contracts to some firms, including Dangote Group, Lafarge Africa, Unilever Nigeria, Flour Mills, to invest in 19 road projects in Nigeria. There is a conspiracy that the two-business magnates Dangote-Dangote Group and Otedola-Zenon Petroleum and Gas Ltd, joined the Buhari second term campaign to maintain their relevancy in the business circle.

Prior studies suggest that political connections are formed through owners/investors (Johnson and Mitton 2003), family (Fishman 2001), directors (Faccio 2006; Halford and Li 2019), and state enterprise (Wu et al. 2012a, b). However, in Nigeria, the common channel of forming political ties is through business owners and (or) family members becoming 
politicians or former politicians investing or starting a business. Business owners engage in politics as party sponsors or electoral candidates of a political party. For instance, Femi Otedola was reported to have sponsored the re-election of Chief of Olusegun Obasanjo in 2003 and that pays his way by acquiring a stake in the Transcorp Hilton Hotel, Abuja (state-owned), through his appointment as the Chairman of Transcorp Hilton Hotel (Sahara Reporter 2006). Former politicians such as ministers and members of parliament also use their political influence to establish businesses, beginning with government contracts. Political connections through family ties are also very common in Nigeria. Family members of incumbent politicians also benefit from tapping into the (politician) networks to grow the business. For example, Agha (2017) reported that Abdullahi Babalele' son-inlaw to the former vice president- Atiku Abubakar, used the political influence of Atiku Abubakar to grow his company-Orlean Investment to clinch operating ticket in the Oil and Gas Free Zones Authority, making them among the top firms operating in the oil and gas industry in Nigeria (Agha 2017). Also, political connections in Nigeria are different from other emerging economies such as China, which is dominated by connections through state-owned enterprises (Wu et al. 2012a, b).

Like most African countries, Nigeria has diverse tribal groups, but three ethnic groups, namely Hausa, Igbo, and Yoruba, have dominated politics and business. The Igbo ethnic group, which dominates the Eastern part of Nigeria, is perceived to align closely with the PDP party, whereas the Hausa in the North is known to be controlling the APC. Yoruba in the Western corridor is fairly divided between APC and PDP, with the majority in APC. This simply shows that tribal affiliations play a significant role in making informed decisions. For instance, APC was formed from the regional parties; ACN predominately by Yoruba tribal and CPC, which is affiliated to Northern Nigeria and dominated by the Hausa tribe, have merited its followers to continuously preach for tribalism.

\section{Literature review and hypotheses development}

Previous studies suggest that political connections can be both beneficial and detrimental to firm performance. The argument in support of political connections can be linked to resource-dependency theory and resource-based theory. According to the resource-dependency theory, a firm's growth and survival are dependent on the external environment (Pfeffer and Salancik 1978). Hence, firms find ways to reduce the uncertainty of the external environment through political connections (Hillman and Dalziel 2003; Wong and Hooy 2018). Politicians are perceived as having power and control over most of the resources of the external environment. Therefore, political connections provide firms access to vital resources to which the firm would not usually have had access.

According to Pfeffer and Salancik (1978), firms affiliate with political actors to reduce dependencies on scarce resources controlled by external entities. Researchers have found that political connections are more valuable in the emerging economy because of the uncertainty in the external environment (Mitchell and Joseph 2010; Guo et al. 2014). Empirical evidence shows that political connections facilitate the acquisition of scarce resources in the external environment through loans, government grants, and government contracts (Johnson and Milton 2003; Khwaja and Main 2005; Adhikari et al. 2006; Faccio 2006; Faccio et al. 2006; Hillman et al. 2009; Boubakri et al. 2012; Hill et al., 2014; Tu et al. 2013; Bona-Sánchez et al. 2014; Guo et al. 2014; Jackowiz et al. 2014; Yang et al. 2014; Halford and $\mathrm{Li}$ 2019). Wu et al. (2012a, b) find that politically connected private firms 
enjoy tax benefits. Still, in China, Tu et al. (2013) show that political connections offer preferential treatment to acquirers in the privatization of state firms. Boubakri et al. (2012) show that politically connected firms have a lower cost of equity. Wu et al. (2018) also find that the CEO's political connections increase firm performance in China.

In addition to connecting firms to scarce resources, politicians themselves are intangible resources because of their knowledge, experience with both local and foreign government procedures and policies under the resource-based theory (Agrawal and Knoeber 2001; Ang et al. 2013). Moreover, in developing countries, politicians are well-acclaimed and attract media attention. These intangible characteristics of politicians create a competitive advantage for politically connected firms-PCC (McWilliams et al. 2002; Wu et al. 2012a, b; $\mathrm{Su}$ et al. 2014). Prior research suggests that political connections have a positive impact on firm performance. For example, Goldman et al. (2008) find that firms experienced abnormal stock returns following the announcement of the nomination of a politically connected person on the firm's board. Similarly, Fisman (2001) reveals that firms connected to the Suharto family lost value following several announcements regarding the poor health of Indonesian President Suharto (see also Faccio and Parsely 2007; Ferguson and Hans-Joachim 2008). Shin et al. (2018) also find that politically connected outside directors improve operating performance in Korean chaebol firms. Political connections reduce the negative impact of political conflict and firm-level cost of equity (Pham 2019). Faccio et al. (2006) suggest that political connections influence government financial assistance to distressed firms in developing countries. Halford and Li (2019) also report that politically connected firms are more likely to resolve distress outside of bankruptcy court.

However, political connections outside the government can be harmful to a firm under the vote-seeking behavior of Downs (1957) theory of electoral competition. According to Downs (1957) electoral competition theory, the actions of political parties are aimed at maximizing votes. Therefore, political parties engage in a "win power at all cost" competitive philosophy, including sabotaging people and firms supporting the opposition party. Thus, in a hyper-partisan environment of developing countries, firms are likely to suffer from the failure of their patron to secure power in an election. The party in power is expected to negatively target firms that support the opposition party as a strategy to cripple the activities of the opposition party. Following the electoral competition theory and its associated "win power at all cost" political philosophy, we argue that a political party in government will use an aggressive strategy to restrict access to vital resources that former government members used to have in order to cut the funding of the opposition party. This will have a negative impact on the firm because such politically connected firms were depending on those resources. Also, the party in government is likely to tarnish the image of the opposition party member through unnecessary and biased probing into the contracts of the former government. These activities are expected to have a negative impact on politically connected firms when their party is in opposition.

Furthermore, the government will channel resources towards its favoured firms, which leads to distortion of the market and misallocation of investments, making it harder for politically connected firms in opposition to survive (Shleifer and Robert 1994). For example, Leuz and Oberholzer-Gee (2006) show that firms connected to a political party find it difficult to secure domestic funding when their political party lost power. Also, the government can change the regulatory requirement to cause a negative impact on firms affiliated with the opposition party. As the government is the biggest consumer and client in developing countries, they can change their expenditure pattern by buying from foreign firms if the only local firm is connected to the opposition party. For example, Goldman et al. (2008) show that people in government manipulate government contract systems against 
firms connected to the opposition party. Besides, firms connected to the opposition party are likely to be a victim of resources exclusion, expropriation, and sabotage from sitting governments (Siegel 2007). For example, COMET Shipping Agencies Nigeria Ltd, South Atlantic Petroleum Limited (SAPETRO), and NetCom Development and Investment Limited owned by Theophilus Danjuma, a political alien to Atiku Abubakar (Presidential candidate-opposition party) reportedly financed the campaign of Atiku Abubakar in Taraba State, Nigeria. As a consequence of supporting the opposition party, COMET Shipping Agencies Nigeria Ltd lost its licenses for crude oil shipping (Sepetro 2019).

Drawing on the resource dependency theory, which implies the positive effect of political connections, and the electoral competition theory, which suggests the negative effect of political connections, we hypothesize that:

$\mathrm{H}_{1}$ : Political connections have a positive effect on firm performance when the patron party is in power and a negative effect on firm performance when the patron party is the opposition party.

It is obvious that tribalism, partisan politics, and business are scarcely separable in most developing countries and Nigeria in particular. Because there are fewer alternative ideologies in the politics of developing countries, politicians win votes on tribal lines (Schwarz 1966). From pre-colonialization to date, ethnic tribes and languages have always been part of the decision-making in the country (Schwarz 1966; Mwakikagile 2001; Sklar 2004). Therefore, tribal factor is one of the principal variables that often define political contestations and business arrangements. These have been promoted by the constitution of Nigeria, where the federal character principles are well articulated, and recognized tribalism in the appointments into federal ministries, departments, and agencies (Idris et al. 2018).

Consequently, governments are formed on tribal tickets. Businesses compete for scarce resources and markets, where the government is the biggest supplier and consumer of the economy. On the positive side, the tribal factor within the APC-led Government had promoted businesses within the tribe that dominate the party. For example, the chairman of Dangote Nigeria Ltd came from the Northern part of Nigeria, where the APC has dominancy. Invariably, that counted in his favor with surge growth of the firms with many new plants situated in the northern part of the country (Dangote Rice mills Saminaka, Kebbi State, Nigeria) (VON, 2019). Similarly, the 16 years ruled by PDP have been characterized by tribal factors, most notably in the sharing of oil licenses, among others. For example, The Heir Group, owned by Tony Elumelu, has been a beneficiary of oil license sharing by the PDP-led administration (Owoeye 2018). In a nutshell, tribal factors more often than not only favor the political class that seeks the favor of the government. Such moves have had adverse effects on the economy as many businesses without government back-up end up going down, or reduce their activities due to strict policies. Firms, therefore, take advantage of any tribal connections with the President to improve their performance. Juma (2012) argues that leaders of political parties focused on pursuing tribal interests. Even in the era of democracies, many African countries have reverted to tribal identities as foundations for political competition (Juma 2012). Therefore, support from a President to a firm lead by a tribal colleague may be seen by many as support for its ethnic group and hence win votes, even if the firm is not politically connected to the President's party.

Although boards of directors are found to provide valuable resources to firms, the CEO is responsible for making strategic decisions to improve firm performance (Wu et al. 2018). Directors may come from different ethnic backgrounds and might not have a common decision; hence, a tribal connection between the CEO and the President is more relevant and important than other directors' tribal connections. According to social identity theory (Tajfel et al 1979; Tajfel 1982), individuals classify themselves and others into different 
categories, including ethnicity, tribe, religion and may favor the members of their own group (i.e. same tribe) and have prejudice against the members of other groups (Hewstone et al 2002; Zoogah 2016). Fracassi and Tate (2012) report that CEOs are more likely to appoint directors who share the same tie with CEOs. Similarly, Balsam et al. (2017) find that indirect ties between CEOs and directors are positively associated with higher CEO compensation and lower CEO turnover. Furthermore, the major consumer in transitional economies like Nigeria is the government (Deloitte 2014), which is managed and directed by the President. As ethnic tribalism influences voting behavior, we expect that CEOs sharing the same ethnic background with the President will mitigate the impact of political connections on firms of the opposition party. Thus, incumbent Presidents are likely to favour firms that are managed by people of his/her tribe regardless of the political connections of the firm. Therefore, we hypothesize that:

$\mathrm{H}_{2}$ : Firms with political connections perform better if their CEOs share the same ethnic background as the President.

\section{Research design}

\subsection{Data and sample}

We select our sample from all publicly listed firms on the Nigerian Stock Exchange (NSE) from 2011 to 2018. After excluding firms with missing data, our final sample consists of 144 firms yielding 1152 firm-year observations over eight years. Our sample period is unique because it covers two democratic elections (2011 and 2015). The 2015 election resulted in a change of government, which was very significant because it was the first time in 15 years the PDP had to hand over power to the opposition party. In fact, it was the first time Nigeria experienced a peaceful, democratic change of government since independence. Hence, the sample period covers the PDP's last government term (2011-2015) and APC's first term (2015-2018). We limit the sample period to ensure the same years in government for both parties and to avoid the effect of any undemocratic interruptions such as coups on the results. Furthermore, due to the fact that there are a lot of missing data before 2011 and inadequate information on the variables of interest in databases, we hand-collected data from firms' annual reports (Ntim and Soobaroyen 2013; Gyapong et al. 2016), which were downloaded from company websites.

\subsection{Regression model and variable measurement}

We begin our analysis with a baseline model that tests the impact of political connections on firm performance regardless of the party is in power or opposition.

$$
\begin{aligned}
F_{i t}= & a+\beta_{1} \text { Political }_{i t}+\beta_{2} \text { TotalAssets }_{i t}+\beta_{3} \text { SalesGrowth }_{i t}+\beta_{4} \text { Leverage }_{i t}+\beta_{5} \text { BoardSize }_{i t} \\
& +\beta_{6} \text { NonExecutive }_{i t}+\beta_{7} \text { YearDummies }_{i t}+\beta_{8} \text { IndustryDummies }_{i t}+\varepsilon_{i t}
\end{aligned}
$$

where $F P_{i t}$ is a measure of firm performance using Tobin's Q or Return on Assets (ROA). Political is political connections measured as the proportion of directors connected with a political party. Total Assets is the natural log of total assets, and Sales Growth represents the proportionate change in sales from year to year. Leverage is the ratio of total debt to 
total assets. Board Size is the number of directors on the board, and Non-Executive represents the proportion of non-executive directors on the board.

Next, we introduce an interaction term (X) between political connections (Political) and status of the connected party (PIP or OPP) to test our first hypothesis,

$$
\begin{aligned}
F P_{i t}= & a+\beta_{1} \text { Political }_{i t}+\beta_{2} X_{i t}+\beta_{3} \text { TotalAssets }_{i t}+\beta_{4} \text { SalesGrwoth }_{i t}+\beta_{5} \text { Leverage }_{i t}+\beta_{6} \text { BoardSize }_{i t} \\
& +\beta_{7} \text { NonExecutive }_{i t}+\beta_{8} \text { YearDummies }_{i t}+\beta_{9} \text { IndustryDummies }_{i t}+\varepsilon_{i t}
\end{aligned}
$$

where $X$ is an interaction term between Political connections (Political) and the status of the connected party, either the party is in power $(P I P)=$ Political $* P I P$ or the party is in opposition $(O P P)=$ Political $^{*} O P P$. $P I P$ is equal to 1 if the connected party is power and 0 otherwise. $O P P$ is equal to 1 if the connected party is the major opposition party and 0 otherwise. All other variables remain the same as defined in model 1.

In model 3, we introduce a three-way interaction term $(\mathrm{Z})$ between political connections and tribal relationships with the President (Political*PIP*Tribalism) to test the second hypothesis.

$$
\begin{aligned}
\text { FP }_{i t}= & a+\beta_{1} \text { Tribalism }_{i t}+\beta_{2} \text { Political }_{i t}+\beta_{3} X_{i t}+\beta_{4} Z_{i t}+\beta_{5} \text { TotalAssets }_{i t}+\beta_{6} \text { SalesGrowt }_{i t}+\beta_{7} \text { Leverage }_{i t} \\
& +\beta_{8} \text { BoardSize }_{i t}+\beta_{9} \text { NonExecutive }_{i t}+\beta_{10} \text { YearDummies }_{i t}+\beta_{11} \text { IndustryDummies }_{i t}+\varepsilon_{i t}
\end{aligned}
$$

where Tribalism is a binary variable equal to 1 if the CEO of the firm comes from the same ethnic tribe of the sitting President and 0 otherwise, $X$ is an interaction term between Political Connections (Political) and the status of the connected party; either the party is in power $(P I P)=$ Political $* P I P$ or the party is in opposition $(O P P)=$ Political $^{*} O P P . Z$ is a three-way interaction term among Political ${ }^{*} P I P^{*}$ Tribalism. All other variables remain the same as defined in model 1.

\subsubsection{Dependent variable}

Prior studies use return on assets (ROA), return on equity (ROE), and stock returns to measure firm performance (Goldman et al. 2009; Ang et al. 2013; Wang et al. 2017, 2019), however Bhagata and Black (2002) argue that these measures are short-term and that does not capture the long-term value of political connections. Furthermore, Gyapong et al. (2016) argue that ROA and ROE are subject to earnings management. Therefore, we use Tobin's Q as the measure of firm performance. Tobin's Q is measured by the ratio of the market value of equity, plus the book value of total debts to the book value of total assets. In addition, we use ROA as an alternative performance measure in the robustness tests.

\subsubsection{Independent variables}

Political connections (Political): Prior studies have articulated different ways through which firms are connected politically (Faccio 2006; Wong and Hooy 2018; Wang et al. 2017). Commonly among these are the board of directors' connections, shareholding connections, and family connections. Wong and Hooy (2018) found that connections through the board of directors and shareholders are more stable and beneficial to the firm than other connections through family members and business people. However, connections through directors provided resources, which directly increase firm value compared with the shareholding connection, which provides a monitoring role for effective corporate governance. Also, it is difficult to identify the partisan political connections of shareholders because 
such information is not publicly available. For these reasons, we measured political connections through the board of directors, and our approach is consistent with Goldman et al. 2008). We define that a director is politically connected if he or she is holding or has held a position such as the minister, federal or state member of parliament, national officer of a political party, or government appointee to national office. A politically connected company is a company with at least one politically connected director.

Data on political connections were derived from different sources including directors' background in the annual report, the list of former members of parliament, ministers, and newswire. To ensure the accuracy of the classification of directors on political party ties, we sought clarity from political party officials on directors where we had any doubts. When measuring the extent of political connections in a company, we used the proportionate measure of the number of politically connected directors as a percentage of the total number of directors. We also used the traditional binary coding of 1 if a company had at least one politically connected director or 0 otherwise as a robustness check.

Tribal connections (Tribalism): We measure tribal connections based on the ethnic background of the company CEO and that of the sitting President (Gross et al. 2016). Firms are coded 1 if the CEO is from the same tribe as the President and 0 otherwise. During the PDP's last term (2011-2014), President Jonathan Goodluck is from Ijaw ethnic group in the Bayelsa State. Muhammed Buhari, the President during the 2015-2018 government, is from Hausa Fulani ethnic group in Kastina State.

\subsection{Control variables}

We controlled for other variables that may potentially impact firm performance following the prior studies (Ang et al. 2006; Boubakri et al. 2008; Wu et al. 2012a, b). Firm size is measured by the natural log of total assets (Total Assets), which is used to control for the effect of economies of scale. The free cash flow hypothesis (Jensen 1988) indicates that debt helps in monitoring the opportunistic behavior of management, thereby increasing firm performance (Ilyukhin 2015). This is especially true for developing countries where there is weaker shareholder protection. However, large debt can also negatively affect firm performance because of debt covenants and periodic repayments (Ilyukhin 2015). We use sales growth (Sales growth) measured by the yearly proportionate change in sales to control for the effects of different stages of the business life cycle. Prior studies have found that growth firms experience high performance (Lee and Blevins 1990; Ntim and Soobaroyen 2013; Gyapong et al. 2016). We also control for corporate governance variables such as board size (Board size) and the number of non-executive directors (Non-executive).

\section{Findings and discussion}

\subsection{Univariate analysis}

Table 1 presents descriptive statistics of the full sample. The mean value of the firm performance measured by Tobin's Q is 1.452 , with a minimum of 0.912 , a maximum of 1.894 , and a standard deviation of 0.815 , indicating high variations of performance across the sample firms. The average political connections among the sample firms are about $20 \%$, equivalent to 1-2 politically connected directors on corporate boards. However, the high 
Table 1 Descriptive statistics (full sample)

\begin{tabular}{llllcll}
\hline Variable & No. firms & Mean & Median & Min & Max & SD \\
\hline Tobin's Q & 144 & 1.452 & 1.400 & 0.911 & 1.894 & 0.815 \\
Return on Assets & 144 & 0.21 & 0.273 & -0.110 & 0.373 & 0.133 \\
Political & 144 & 0.202 & 0.151 & 0 & 0.653 & 0.354 \\
Total Assets & 144 & 415 & 843 & 0.500 & 5955 & 914 \\
Sales Growth & 144 & 0.304 & 0.262 & -0.092 & 0.531 & 0.104 \\
Leverage & 144 & 0.243 & 0.193 & 0 & 0.632 & 0.151 \\
Board Size & 144 & 9 & 7 & 5 & 17 & 3 \\
Non-Executive & 144 & 5 & 3 & 1 & 9 & 5 \\
Tribalism & 144 & 0.381 & 0.320 & 0 & 1 & 0.745 \\
\hline
\end{tabular}

This table presents the descriptive statistics of the full sample. Variables are defined as follows: Tobin's $Q$-The ratio of the market value of equity plus the book value of total debts to the book value of total assets. Return on Assets -The ratio of net profit before tax to total assets. Political-Proportion of directors who are affiliated with a political party. Total Assets-Total assets of the company measured in Billions of Nara. Sales Growth-Proportionate change in sales from year to year. Leverage-total debt to total assets. Board Size-Number of directors on the board. Non-executive-Number of non-executive directors on the board. Tribalism - It is a binary variable equal to 1 if the CEO of the firm comes from the same ethnic tribe of the President and 0 otherwise

Table 2 The number of companies by partisan political connections

\begin{tabular}{lccccc}
\hline Year & NPCC & PIP & OPP & Multiple & Total \\
\hline 2011 & 67 & 43 & 27 & 7 & 144 \\
2012 & 64 & 45 & 28 & 7 & 144 \\
2013 & 65 & 45 & 25 & 9 & 144 \\
2014 & 62 & 45 & 29 & 8 & 144 \\
2015 & 54 & 32 & 47 & 11 & 144 \\
2016 & 52 & 35 & 46 & 11 & 144 \\
2017 & 47 & 37 & 47 & 13 & 144 \\
2018 & 48 & 43 & 41 & 12 & 144 \\
Total & 449 & 323 & 292 & 78 & 1152 \\
\hline
\end{tabular}

This table presents the number of companies and observations by partisan political connection. $N P C C$-non-politically connected companies. $P I P$-companies connected to the party in power. $O P P-$ companies connected to the main opposition party. Multiple-companies that have political connections with more than one political party

standard deviation indicates high variations as some firms have three politically connected directors, and others have none. The maximum of 0.653 for Political shows that some firms have more than half of their directors connected to politicians through different channels, especially firms with connections to multiple parties. The average board size is 9 , with an average of 5 members being non-executive directors. Over the sample period, the firms had a mean of $30 \%$ growth in sales.

To investigate the distribution of politically connected firms, we classified the sample firms according to being connected with the party in power (PIP) or opposition party (OPP) in a particular year. Table 2 shows that out of 1152 firm-year observations, only 
Table 3 T-test of the mean (median) difference by partisan political connections

\begin{tabular}{|c|c|c|c|c|c|c|c|}
\hline \multirow[b]{2}{*}{ Variable } & \multicolumn{4}{|c|}{ Mean (Median) } & \multicolumn{3}{|l|}{ T-test results } \\
\hline & NPCC & PIP & OPP & MUT & NPCC vs. PIP & NPCC vs. OPP & PIP vs. OPP \\
\hline & (1) & (2) & (3) & (4) & (5) & (6) & (7) \\
\hline Tobin's Q & $\begin{array}{l}1.32 \\
(1.35)\end{array}$ & $\begin{array}{l}1.68 \\
(1.73)\end{array}$ & $\begin{array}{l}1.22 \\
(1.19)\end{array}$ & $\begin{array}{l}1.33 \\
(1.36)\end{array}$ & $\begin{array}{l}4.60 * * * \\
(3.99 * * *)\end{array}$ & $\begin{array}{l}1.97 * * \\
(2.01 * *)\end{array}$ & $\begin{array}{l}4.28 * * * \\
(3.33 * * *)\end{array}$ \\
\hline Total Assets & $\begin{array}{l}417 \\
(339)\end{array}$ & $\begin{array}{l}587 \\
(605)\end{array}$ & $\begin{array}{l}515 \\
(495)\end{array}$ & $\begin{array}{l}372 \\
(199)\end{array}$ & $\begin{array}{l}1.99 * * \\
(2.17 * * *)\end{array}$ & $\begin{array}{l}1.96 * * \\
(1.87 *)\end{array}$ & $\begin{array}{l}1.56 \\
(1.63)\end{array}$ \\
\hline Sales Growth & $\begin{array}{l}0.31 \\
(0.36)\end{array}$ & $\begin{array}{l}0.36 \\
(0.31)\end{array}$ & $\begin{array}{l}0.26 \\
(0.23)\end{array}$ & $\begin{array}{l}0.22 \\
(0.41)\end{array}$ & $\begin{array}{l}2.11 * * \\
(2.68 * * *\end{array}$ & $\begin{array}{l}1.98 * * \\
\left(2.15^{* *}\right)\end{array}$ & $\begin{array}{l}2.36 * * \\
\left(2.13^{* *}\right)\end{array}$ \\
\hline Leverage & $\begin{array}{l}0.17 \\
(0.23)\end{array}$ & $\begin{array}{l}0.32 \\
(0.53)\end{array}$ & $\begin{array}{l}0.26 \\
(0.43)\end{array}$ & $\begin{array}{l}0.26 \\
(0.33)\end{array}$ & $\begin{array}{l}3.25 * * * \\
(2.87 * * *)\end{array}$ & $\begin{array}{l}1.73 * \\
(1.49)\end{array}$ & $\begin{array}{l}1.56 \\
(1.39)\end{array}$ \\
\hline Board Size & $\begin{array}{l}8 \\
(8)\end{array}$ & $\begin{array}{l}9 \\
(10)\end{array}$ & $\begin{array}{l}9 \\
(9)\end{array}$ & $\begin{array}{l}10 \\
(9)\end{array}$ & $\begin{array}{l}0.58 \\
(0.99)\end{array}$ & $\begin{array}{l}1.23 \\
(1.19)\end{array}$ & $\begin{array}{l}0.11 \\
(0.67)\end{array}$ \\
\hline Non-Executive & $\begin{array}{l}4 \\
(5)\end{array}$ & $\begin{array}{l}7 \\
(7)\end{array}$ & $\begin{array}{l}7 \\
(6)\end{array}$ & $\begin{array}{l}5 \\
(6)\end{array}$ & $\begin{array}{l}1.75^{*} \\
(1.63)\end{array}$ & $\begin{array}{l}1.77 * \\
(1.41)\end{array}$ & $\begin{array}{l}1.32 \\
(0.29)\end{array}$ \\
\hline Observations & 459 & 323 & 292 & 78 & 782 & 751 & 615 \\
\hline
\end{tabular}

This table presents sample distribution and T-tests by type of partisan connection. Variables are defined as follows: Tobin's $Q$ - The ratio of the market value of equity plus the book value of total debts to the book value of total assets. Total Assets-Total assets of the company measured in Billions of Nara. Sales growth-Proportionate change in sales from year to year. Leverage-total debt to total assets. Board size-Number of directors on the board. Non-executive-Number of non-executive directors on the board. NPCC-non-politically connected companies. PIP - companies connected to the party in power. OPPcompanies connected to the main opposition party. $M U T$-companies that have political connections with more than one political party

449 firm-year observations (NPCC) did not have politically connected directors on their boards. The remaining firms had at least one director connected with one or more political parties. It can be seen that 323 firm-year observations have a connection with PIP, while 292 firm-year observations are connected to the OPP. The significant increase of the firms connected with the OPP party from 2015 is because PDP, which has been in government for a long time (1999-2015), lost the election and became the opposition party. However, from 2011 to 2014, 5 firms connected to APC shifted to PDP by 2015, and 2 firms appointed PDP connected director in addition to having APC connected director. Between 2015 to 2018, when there was a change in government from PDP to APC, we found that 7 firms switched their political connection from PDP to APC while 4 firms established multiple political connections with APC. Some firms previously affiliated with PDP gradually moved to APC. For example, Dangote, the founder of the Dangote group of companies, a premium sponsor of PDP, was announced to be a member of the APC campaign advisory team in 2018 (The Africa Report 2015; Bloomberg 2018). We also find that 78 firm-year observations had multiple connections with both PIP and OPP parties.

Table 3 presents the mean (median) statistics of the variables according to the status of the political party connected with. The mean value of Tobin's Q indicates that PIP (1.68) performed better than non-politically connected firms (1.32). However, the average performance of firms connected with OPP (1.22) is lower than non-politically connected firms (1.32), suggesting that firms underperform when their patron party falls from power. Both firm characteristics and governance structures reported in Table 3 
Table 4 Pearson correlation matrix

\begin{tabular}{|c|c|c|c|c|c|c|c|}
\hline Variable & 1 & 2 & 3 & 4 & 5 & 6 & 7 \\
\hline 1. Tobin's Q & 1 & & & & & & \\
\hline 2. Political & $0.220 * *$ & 1 & & & & & \\
\hline 3. Total Assets & $0.141 *$ & $0.373 *$ & 1 & & & & \\
\hline 4. Sales Growth & $0.563 * * *$ & $0.284 * *$ & -0.008 & 1 & & & \\
\hline 5. Leverage & $-0.134 *$ & 0.111 & 0.270 & 0.211 & 1 & & \\
\hline 6. Board Size & 0.162 & $0.313^{*}$ & 0.261 & 0.070 & $0.280 * *$ & 1 & \\
\hline 7. Non-Executive & 0.009 & $0.280 * *$ & 0.144 & $0.060^{*}$ & 0.214 & $0.445 * *$ & 1 \\
\hline
\end{tabular}

This table presents Pearson's pairwise correlation among the variables. Variables are defined as follows. Tobin's $Q$-The ratio of the market value of equity plus the book value of total debts to the book value of total assets. Political-Proportion of directors who are affiliated with a political party. Total Assets-Total assets of the company measured in Billions of Nara. Sales Growth-Proportionate change in sales from year to year. Leverage-Total debt to total assets. Board size-Number of directors on the board. Non-executive-Number of non-executive directors on the board. $* * *, * *$, and $*$ denote statistical significance at the $1 \%, 5 \%$, and $10 \%$ level, respectively

indicate that they have similar features regardless of the political connections. We use a T-test of mean (median) difference to statistically check if the differences between variables of different status of political connections are significant. Table 3 shows that the mean differences of Tobin's Q between non-political connected firms (NPCC) and PIP is highly significant. Similarly, the performance of firms connected to PIP and OPP are significantly different. Another significant difference between PIP and OPP is the growth in sales. PIP has higher sales growth than OPP because PIP can easily gain access to government contracts, which turn out to be the largest customer in most developing countries. The company size measured by Total Assets is similar for both PIP and OPP. These preliminary findings set the tone that the impact of political connection on firm performance depends on the status of the patron party, either as the party in power or the opposition party.

Table 4 contains the results for the test of multicollinearity from the Pearson correlation matrix. The results do not suggest any high correlation among the variables of interest and indicate that there are no serious multicollinearity problems in our models (Liu et al. 2014). We also test for other linear regression assumptions, such as autocorrelation, normality, homoscedasticity, and linearity. These tests do not indicate any possible violation of any of the linear assumptions. For brevity, these results are not reported.

\subsection{Multivariate analysis}

\subsubsection{Baseline results}

Previous literature suggests that firms differ from each other in terms of their organizational culture, complexity, and managerial talents (Guest 2009; Ntim and Soobaroyen 2013); thus, the use of panel data has the advantage of mitigating individual heterogeneity (Baltagi 1998). Park (2011) argued that company-specific differences are best controlled if the appropriate panel data technique is performed. To choose the most suitable estimation between pooled OLS and fixed effect/random effect, we performed both the Lagrange 
Table 5 Regression results on the impact of political connections on firm performance

\begin{tabular}{|c|c|c|c|c|}
\hline Variable & $\begin{array}{l}\text { Tobin's Q } \\
\text { (1) }\end{array}$ & $\begin{array}{l}\text { Tobin's Q } \\
\text { (2) }\end{array}$ & $\begin{array}{l}\text { ROA } \\
\text { (3) }\end{array}$ & $\begin{array}{l}\text { ROA } \\
(4)\end{array}$ \\
\hline Political (\%) & $\begin{array}{l}0.098 * * * \\
(5.71)\end{array}$ & & $\begin{array}{l}0.119 * * * \\
(17.13)\end{array}$ & \\
\hline Political (Binary) & & $\begin{array}{l}0.153 * * * \\
(2.76)\end{array}$ & & $\begin{array}{l}0.213 \text { *** } \\
(4.12)\end{array}$ \\
\hline Total assets & $\begin{array}{l}0.014 * * \\
(1.98)\end{array}$ & $\begin{array}{l}0.012 * \\
(1.76)\end{array}$ & $\begin{array}{l}0.018 * * \\
(1.95)\end{array}$ & $\begin{array}{l}0.028 * * \\
(1.97)\end{array}$ \\
\hline Sales growth & $\begin{array}{l}0.17 * * * \\
(8.23)\end{array}$ & $\begin{array}{l}0.257 * * * \\
(10.12)\end{array}$ & $\begin{array}{l}0.213 * * * \\
(9.34)\end{array}$ & $\begin{array}{l}0.194 * * * \\
(6.14)\end{array}$ \\
\hline Leverage & $\begin{array}{l}-0.02 * \\
(-1.08)\end{array}$ & $\begin{array}{l}-0.018 * \\
(-1.69)\end{array}$ & $\begin{array}{l}-0.007 * \\
(-1.83)\end{array}$ & $\begin{array}{l}-0.003 \\
(-1.63)\end{array}$ \\
\hline Board size & $\begin{array}{l}0.008 \\
(1.23)\end{array}$ & $\begin{array}{l}0.011 \\
(1.49)\end{array}$ & $\begin{array}{l}0.009 \\
(1.59)\end{array}$ & $\begin{array}{l}0.009 \\
(1.61)\end{array}$ \\
\hline Non-executive & $\begin{array}{l}0.003 \\
(0.812)\end{array}$ & $\begin{array}{l}0.002 \\
(0.765)\end{array}$ & $\begin{array}{l}0.004 \\
(0.654)\end{array}$ & $\begin{array}{l}0.004 \\
(0.691)\end{array}$ \\
\hline Constant & $\begin{array}{l}0.612 * * * \\
(14.08)\end{array}$ & $\begin{array}{l}0.345^{* * *} \\
(10.87)\end{array}$ & $\begin{array}{l}0.834 * * * \\
(17.879)\end{array}$ & $\begin{array}{l}0.896 * * * \\
(14.179)\end{array}$ \\
\hline Industry effect & Yes & Yes & Yes & Yes \\
\hline Year effect & Yes & Yes & Yes & Yes \\
\hline Adj-R & 0.456 & 0.294 & 0.401 & 0.394 \\
\hline Observations & 1152 & 1152 & 1152 & 1152 \\
\hline
\end{tabular}

This table presents the regression results of the overall impact of political connections on firm value. Political (\%)_-Proportion of directors who are affiliated with a political party. Political (Binary) - It is a binary variable equal to 1 if at least one director of the firm has political affiliation with any party and 0 otherwise. Tobin's $Q-$ The ratio of the market value of equity plus the book value of total debts to the book value of total assets. Total Assets-Total assets of the company measured in Billions of Nara. Sales growth-Proportionate change in sales from year to year. Leverage-total debt to total assets. Board size-Number of directors on the board. Non-executive-Number of non-executive directors on the board. $t$-Statistics are shown in parentheses. $* * *, * *$, and $*$ denote statistical significance at the $1 \%, 5 \%$, and $10 \%$ level, respectively

Multiplier (L.M.) test (Breusch and Pagan 1980) and the Hausman (1978) test. Based on those two tests, we adopted the fixed effects model.

Table 5 presents the multivariate regression results of the impact of political connections on firm performance. Column (1) shows the political connections, which is measured as the percentage of politically connected directors on the board, have strong predictive power in explaining the variation in firm performance. We obtained similar results when the political connection is measured as a binary variable (see Column (2) of Table 5). Both results indicate that political connections are statistically significant in improving firm performance. We replace Tobin's Q with ROA as an alternative measure of firm performance in the results of columns (3) and (4). The results are not statistically different from those of columns (1) and (2). Therefore, the results are robust to an alternative measure of political connection and firm performance. The results of the control variables are consistent with our expectations and prior studies. 
For example, as predicted, company size and sales growth are positive and significant determinants of firm performance. Leverage, on the other hand, has a negative impact on firm value.

\subsubsection{The impact of political connections conditioned on the status of the patron party}

Table 6 reports the results of the impact of political connections conditioned on the status of the patron party (PIP or OPP) on firm performance. We provide results across three different periods. Full sample period (2011-2018) in columns 1-3, the PDP term 2011-2014 in columns 4-6, and APC term 2015-2018 in columns 7-9. Across all three different periods, our primary variable of interest is the interaction term (Political*PIP) or (Political*OPP). The overarching objective is to estimate the differences, if any, of political connection to firm performance when the politically connected director's party was in government and when in opposition.

Column (1) of Table 6 shows that firms connected to PIP experience more benefits as the coefficient of Political*PIP (0.121) is significant and greater than 0.032 of Political. Thus, directors who are connected to the PIP add more value to the firm than directors connected to other parties. In economic terms, all other things being equal, one director connected with the party in power will increase firm performance by $0.212[(0.12 * 0.354 / 0.202)]^{1}$ or $14.6 \%(0.212 / 1.452)$.

On the contrary, the results in Column (2) indicate that firms connected to OPP experience negative performance. The negative and significant coefficient of Political*OPP ( -0.016$)$ compared with the positive and significant coefficient of Political (0.041) implies that when a firm's patron party falls to the opposition, its performance starts to deteriorate. In economic terms, all other things being equal, a political connection to the opposition party through one director decreases the firm's performance by 0.045 $[(0.098 * 0.354) / 0.202]$ or $3.13 \%(0.045 / 1.452)$. In Column (3), we test whether having directors connected to different political parties add value to the firm. The results indicate that multiple political connections do improve firm performance $(0.011)$ but at a marginal rate at the $10 \%$ significance level. Comparatively, multiple connections are better than no political connections and connections with the opposition party, but not better than a single-party connection to the party in power. Arguably, multiple connections are too expensive to keep because the firm needs to sponsor more than one party, and likely to result in a conflict of interest among politically connected directors. There is a potential conflict of interest because each party might not see the firm as a strong ally for better deals.

During the PDP government era (2011-2014) in Columns 4-6, we find that firms connected to the party in power (PIP) (that is, firms connected with PDP) have a positive and significant impact on firm performance, which are similar to the results of the full sample. However, political connections had a significant and negative impact on firms connected with OPP (that is, firms connected with APC) during the same period when PDP was in government. Specifically, political connections increase firm performance by $13.5 \%$ if the company was connected to PDP (party in power). However, firms connected with APC (the opposition party) lost about 3.3\% in value during the PDP government era. Moreover, during the APC government era in 2015-2018 (Columns 7-9), when APC took over power

\footnotetext{
1 We follow Adhikari and Agrawal (2016) approach as follows: coefficient of political connection PIP $(\mathrm{OPP})^{*}$ standard deviation of political connection/mean of political connection.
} 


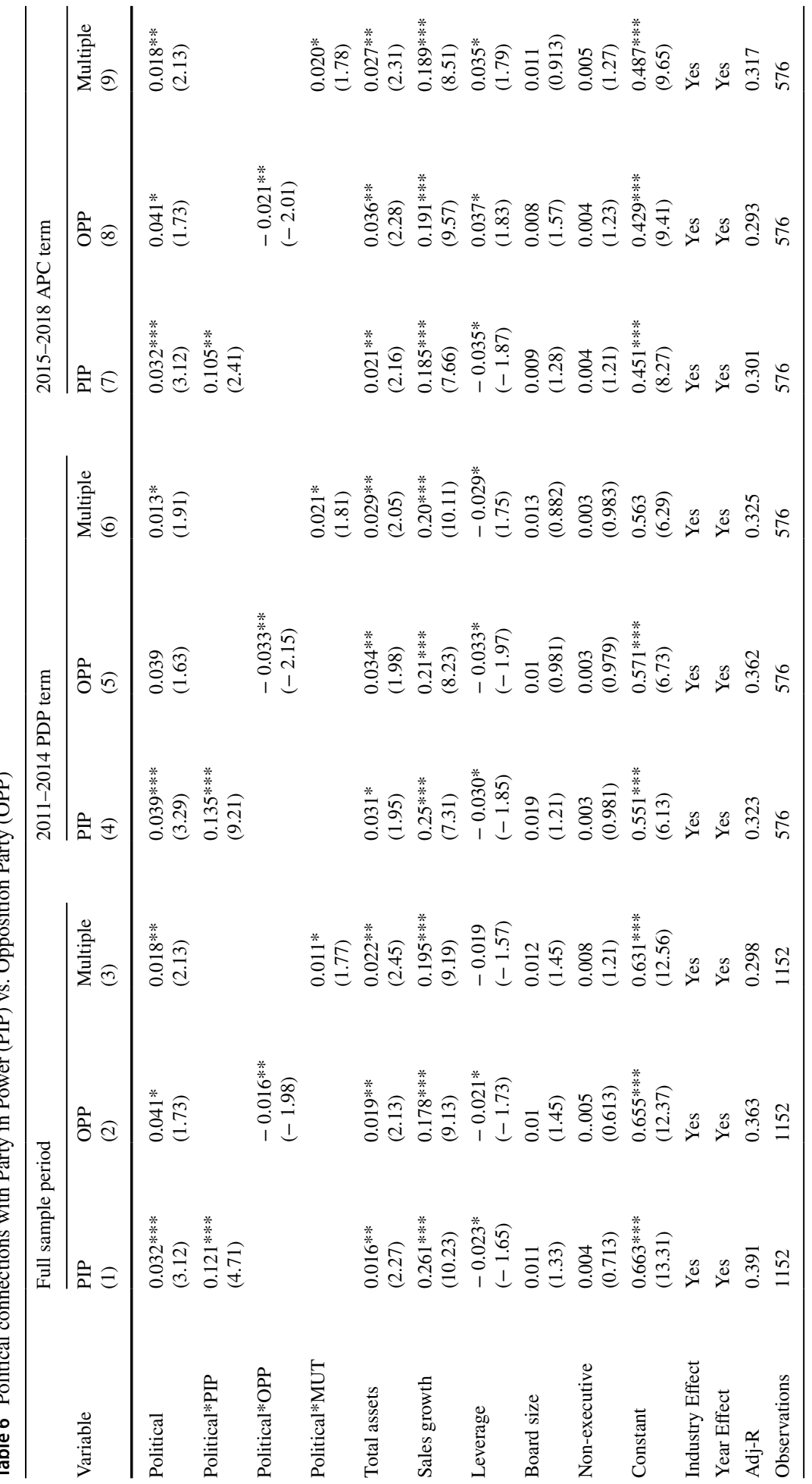




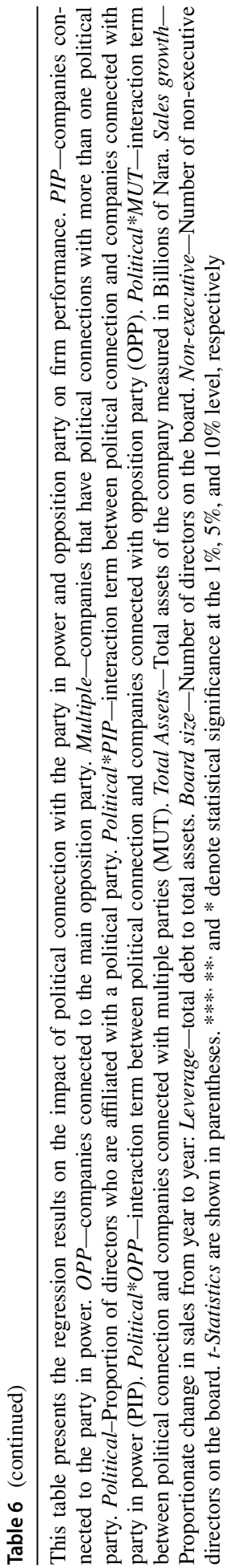


from PDP, we find that firms connected with the party in power (now the APC) enhance firm performance whereas firms connected with the opposition party (now the PDP) underperformed. The findings suggest that in a highly partisan country, politically connected people have better access to resources when their party is in power. Another possible reason why firms underperform when their patron party falls from power is that such firms may have sponsored their patron party with the expectation of getting good deals to offset its significant sponsorship when their patron gets elected. Such sponsorship can cripple the investment and working cash flow of the firm, especially when the patron does not win the election. Firms with connections with different parties had a significant value contribution from their politically connected directors. Thus, multiple-party connections have value relevance regardless of the party in government. Political connections with multiple parties are likely to give firms continuous value with the government of the day. Overall, our results support $\mathrm{H}_{1}$ that the impact of political connection varies depending on whether the party is in government or opposition during the period.

Although our empirical analysis shows that political connection is beneficial where the firm is connected to the party in power, it does not go without saying that political connection with any political party, regardless of its status, comes without costs. Obviously, been connected with a political figure comes at a price that can be monetary, non-monetary, or both. For example, connected firms are expected to sponsor the political campaign of their parties. These sponsorships require an outflow of a large sum of money. For example, The Africa Report (2015) claim that Skye Bank and its group of companies donated 1 billion Naira towards the PDP campaign in 2014. Firms in Nigeria do not disclose these contributions to political parties. Firms are likely to pay for directors, who might be too busy to attend meetings and monitor management. Politically connected directors are found to be busy, and hence their lack of attendance at meetings could impair the overall performance of the firm (Pascual-Fuster and Crespí-Cladera 2018). While it could be more informative to account for the busyness of directors in our model, there are no disclosures on the number of directorships in the annual reports or database. Regarding the non-monetary cost, in a hyper-partisan political environment, some political connection could lead to serotyping on the firms (Bianchi et al. 2013). Being known to be connected with the government might appear to many people as supporting the government agenda. Hence people who do not support the government might avoid the firm's products and services. Also, a highlevel connection with the government could be interpreted as a breeding ground for corrupt contracts that might help tarnish the firm's reputation (Jin et al. 2019). We acknowledge that the non-inclusion of these factors in our model could potentially bias our results. In the absence of accurate data and given the increasing number of firms' connections with the party in power, we argue that the benefit of political connection with the party in power outweighs the cost.

\subsubsection{Partisan politics and firm performance conditioned on tribalism}

Given the tribal environment of Nigeria, we use CEO ethnic connections with the President of the country to estimate how firms use tribalism to their advantage. By doing this, we provide evidence of tribalism on firm performance. Second, we provide empirical findings 
Table 7 Regression results of partisan politics and firm performance conditioned on tribalism

\begin{tabular}{|c|c|c|c|c|c|c|c|}
\hline \multirow{3}{*}{ Variable } & \multicolumn{2}{|l|}{ Full period } & \multicolumn{2}{|c|}{ 2011-2014 PDP term } & \multicolumn{2}{|c|}{ 2015-2018 APC term } & \multirow{3}{*}{$\begin{array}{l}\text { NPCC } \\
\text { (7) }\end{array}$} \\
\hline & PIP & OPP & PIP & OPP & PIP & OPP & \\
\hline & (1) & (2) & (3) & (4) & (5) & (6) & \\
\hline Tribalism & $\begin{array}{l}0.017 * * \\
(2.19)\end{array}$ & $\begin{array}{l}0.013 * * \\
(2.23)\end{array}$ & $\begin{array}{l}0.012 * * \\
(2.13)\end{array}$ & $\begin{array}{l}0.010^{* * *} \\
(2.23)\end{array}$ & $\begin{array}{l}0.015^{* *} \\
(2.39)\end{array}$ & $\begin{array}{l}0.014 * * \\
(2.55)\end{array}$ & $\begin{array}{l}0.016 * * \\
(2.460)\end{array}$ \\
\hline Political & $\begin{array}{l}0.037 * * * \\
(3.19)\end{array}$ & $\begin{array}{l}0.009 * * \\
(2.41)\end{array}$ & $\begin{array}{l}0.114 * * \\
(2.10)\end{array}$ & $\begin{array}{l}0.109 * * * \\
(1.97)\end{array}$ & $\begin{array}{l}0.112 * \\
(1.87)\end{array}$ & $\begin{array}{l}0.116^{* * *} \\
(1.99)\end{array}$ & \\
\hline Political*PIP & $\begin{array}{l}0.129 * * * \\
(4.56)\end{array}$ & & $\begin{array}{l}0.19 * * * \\
(9.26)\end{array}$ & & $\begin{array}{l}0.115^{* * *} \\
(2.76)\end{array}$ & & \\
\hline Political*PIP*Tribalism & $\begin{array}{l}0.212^{* * *} \\
(6.11)\end{array}$ & & $\begin{array}{l}0.21 * * * \\
(8.37)\end{array}$ & & $\begin{array}{l}0.143^{* * *} \\
(5.16)\end{array}$ & & \\
\hline Political*OPP & & $\begin{array}{l}-0.011^{* *} \\
(-1.99)\end{array}$ & & $\begin{array}{l}-0.02 * * \\
(-2.43)\end{array}$ & & $\begin{array}{l}-0.009^{* *} \\
(-2.25)\end{array}$ & \\
\hline Political*OPP*Tribalism & & $\begin{array}{l}0.007 * * \\
(1.84)\end{array}$ & & $\begin{array}{l}0.003 * \\
(1.81)\end{array}$ & & $\begin{array}{l}0.024 * \\
(2.17)\end{array}$ & \\
\hline Constant & $\begin{array}{l}0.301^{* * *} \\
(5.33)\end{array}$ & $\begin{array}{l}0.311 * * * \\
(5.37)\end{array}$ & $\begin{array}{l}0.262 * * * \\
(4.12)\end{array}$ & $\begin{array}{l}0.251 * * * \\
(4.17)\end{array}$ & $\begin{array}{l}0.313^{* * *} \\
(6.10)\end{array}$ & $\begin{array}{l}0.329 * * * \\
(7.65)\end{array}$ & $\begin{array}{l}0.211^{* * *} \\
(5.86)\end{array}$ \\
\hline Controls & YES & YES & YES & YES & YES & YES & YES \\
\hline Year effect & YES & YES & YES & YES & YES & YES & YES \\
\hline Industry effect & YES & YES & YES & YES & YES & YES & YES \\
\hline Adj. $R$ & 0.372 & 0.318 & 0.396 & 0.399 & 0.365 & 0.378 & 0.294 \\
\hline Observations & 1152 & 1152 & 526 & 526 & 576 & 576 & 449 \\
\hline
\end{tabular}

This table presents the regression results of partisan politics and firm performance conditioned on tribalism. $P I P$-companies connected to the party in power. $O P P$-companies connected to the main opposition party. Tribalism - It is a dummy variable equal to 1 if the CEO is from the same tribe as the President and 0 otherwise. Political-Proportion of directors who are affiliated with a political party. Political*PIP-interaction term between political connection and companies connected with party in power (PIP). Political*OPPinteraction term between political connection and companies connected with opposition party (OPP). Political ${ }^{*} P I P^{*}$ Tribalism - a three-way interaction term between political connection and companies connected with party in power (PIP) and tribalism. Political*OPP*Tribalism-a three interaction term between political connection and companies connected with opposition party (OPP) and tribalism. t-Statistics are shown in parentheses. $* * *, * *$, and $*$ denote statistical significance at the $1 \%, 5 \%$, and $10 \%$ level, respectively

on how a company mitigates the downside of political connections through tribalism. Our sample provides unique settings for such analysis because there are two Presidents from two different ethnic backgrounds during the sample period. In the sample, 326 observations had a CEO with an ethnic group as the Presidents. 112 of these observations change their CEOs within 18 months following the change of government.

The results of the regression estimation are presented in Table 7. The coefficient of a three-way interaction term (Political*PIP*Tribalism) in Column (1) is significant and greater than a two-way interaction if a company's patron party is in power (Political*PIP), implying that tribal connections provide an incremental contribution to firms on top of political connections. In economic terms, all other things being equal, the tribal connection 
between the CEO and the President increases firm performance to $18.85 \%$ from $14.60 \%$ (see the economic significance of results in Table 6) in the case of firms connected to the party in power. ${ }^{2}$ Regarding firms connected to the opposition party, tribalism minimizes the decrease in performance from $3.13-0.5 \%$ (see the economic significance of results in Table 6). We observe a similar trend in the PDP term (2011-2014) in Column (3) and APC term (2015-2018) in Column (5). The results in Columns (3) and (4) indicate that firms connected to APC, which was the main opposition party, during the PDP term underperformed. However, firms connected with APC but had the CEO coming from the same tribe with President Goodluck (of PDP) experience positive performance. The same results can be found when firms connected to PDP (opposition party) during the APC term (2015-2018).

The results imply that firms politically connected to the opposition party but have a tribal connection with the President do not experience negative performance compared to other similar firms with the opposition party without tribal connections to the President. To put it differently, a firm connected with PDP performed fairly well under the APC era of 2015-2018 if its CEO was from the Hausa Fulani ethnic group, which is the tribe of President Muhammed Buhari. The same can be found when firms connected with APC under President Goodluck Jonathan if the CEO is from the Ijaw ethnic group. Therefore, our results provide evidence supporting $\mathrm{H}_{2}$ where politically connected firms perform much better if it has a CEO who shares the same ethnic background as the President, regardless of the status of the patron party. We, therefore, argue that firms that are in opposition could minimize their damage from political connections by appointing a new CEO whose tribal affiliation is the same as that of the President.

Although this paper focuses on firms with political connections, we perform additional analysis to test whether tribalism is beneficial to firms without political connections. The results are presented in column 7 of Table 7 . The results show that the coefficient of Tribalism is positive and significant, which indicates that a firm's tribal connection with the President can serve as a positive resource that enhances firm performance. In economic terms, all other things being equal, a tribal connection with the President can increase a firm's performance by $2.15 \%$. By extension, our results confirm our findings that a firm's tribal connection can minimize the potential downside of political connection when the patron party falls to the opposition.

\subsubsection{Endogeneity}

First, to address the possible endogeneity concerns that may arise from omitted variable bias, two-stage least squares (2SLS) model has been estimated. In the first stage of the 2SLS analysis, we estimated the factors that are likely to influence firms to appoint politically connected persons on board. We also considered factors that may attract politically connected persons to serve on the board of a company. These factors include the size (Total Assets), the profitability of the company (ROA), age (AGE), ownership structures (FORWN) of the company. Because firms benchmark their activities against other firms within the industries, the company's decision to appoint a politically connected person is

\footnotetext{
${ }^{2}$ We follow the previous studies (Asongu and Nwachukwu 2018; Tawiah and Karungi 2020) to calculate the net economic effect $=[$ (mean of tribalism*interaction term + coefficient of political connection $\mathrm{PIP}(\mathrm{OPP}) /$ mean of Tobin's Q].
} 
Table 8 Endogeneity tests

\begin{tabular}{|c|c|c|c|c|c|c|c|}
\hline \multirow[t]{3}{*}{ Variable } & \multirow{3}{*}{$\begin{array}{l}\text { 1st stage } \\
\text { (1) }\end{array}$} & \multirow{3}{*}{$\begin{array}{l}\text { 2SLS } \\
\text { (2) }\end{array}$} & \multirow{3}{*}{$\begin{array}{l}\text { GMM } \\
\text { (3) }\end{array}$} & \multirow{3}{*}{$\begin{array}{l}\text { DID } \\
\text { (4) }\end{array}$} & \multirow{3}{*}{$\begin{array}{l}\text { DID } \\
(5)\end{array}$} & \multicolumn{2}{|c|}{ Additional control } \\
\hline & & & & & & PIP & OPP \\
\hline & & & & & & (6) & (7) \\
\hline ROA & $\begin{array}{l}0.403 * * * \\
(4.99)\end{array}$ & & & & & & \\
\hline FOROWN & $\begin{array}{l}0.031 * \\
(1.71)\end{array}$ & & & & & & \\
\hline INRatio & $\begin{array}{l}0.379 * * * \\
(7.13)\end{array}$ & & & & & & \\
\hline Age & $\begin{array}{l}0.013 \\
(1.59)\end{array}$ & & & & & & \\
\hline РPCB & & $\begin{array}{l}0.012 * * * \\
(9.18)\end{array}$ & $\begin{array}{l}0.11 * * * \\
(8.03)\end{array}$ & & & & \\
\hline DID & & & & $\begin{array}{l}-0.089^{* * *} \\
(-2.89)\end{array}$ & $\begin{array}{l}-0.112 * * * \\
(-3.32)\end{array}$ & & \\
\hline Treatment & & & & $\begin{array}{l}-0.062^{* *} \\
(-2.30)\end{array}$ & $\begin{array}{l}-0.079^{*} \\
(-1.81)\end{array}$ & & \\
\hline Post-election & & & & $\begin{array}{l}0.045 \\
(1.06)\end{array}$ & $\begin{array}{l}0.037 \\
(0.98)\end{array}$ & & \\
\hline Political & & & & & & $\begin{array}{l}0.023 * * \\
(2.03)\end{array}$ & $\begin{array}{l}0.031^{* *} \\
(1.99)\end{array}$ \\
\hline Political*PIP & & & & & & $\begin{array}{l}0.109 * * * \\
(3.09)\end{array}$ & \\
\hline Political*OPP & & & & & & & $\begin{array}{l}-0.012 * * \\
(-2.01)\end{array}$ \\
\hline Board_Tribe & & & & & & $\begin{array}{l}0.008^{*} \\
(1.88)\end{array}$ & $\begin{array}{l}0.009^{*} \\
(1.76)\end{array}$ \\
\hline Constant & $\begin{array}{l}1.67 * * * * \\
(5.33)\end{array}$ & $\begin{array}{l}0.61 * * * \\
(4.19)\end{array}$ & $\begin{array}{l}0.69 * * * \\
(7.17)\end{array}$ & $\begin{array}{l}1.02 * * * \\
(9.91)\end{array}$ & $\begin{array}{l}1.152 * * * \\
(10.11)\end{array}$ & $\begin{array}{l}0.18^{* * * *} \\
(6.61)\end{array}$ & $\begin{array}{l}0.18 * * * * \\
(6.04)\end{array}$ \\
\hline Controls & Yes & Yes & Yes & Yes & Yes & Yes & Yes \\
\hline Industry Effect & Yes & Yes & Yes & Yes & Yes & Yes & Yes \\
\hline Adj. R & 0.476 & 0.382 & 0.325 & 0.265 & 0.291 & 0.266 & 0.287 \\
\hline Observations & 1152 & 1152 & 1152 & 1152 & 1152 & 1152 & 115 \\
\hline
\end{tabular}

This table presents the results of the endogeneity test. Columns 1 shows the first stage of the Two-stage least squares (2SLS) regressions. Columns 2 and 3 show the 2nd stage and GMM results. Columns 4 and 5 report the results for the difference in differences regression. Column 4 is based on PDP-connected firms as the treatment against non-politically connected as the control group. Column 5 is based on PDP connected as the treatment group against APC connected firms as the control group. In columns 6-7, we control for the effect of board members' tribal connection with the President. Tobin $Q$ is lagged by one year. FOROWN - the percentage of foreign ownership. INRatio-industry ratio of political connection. Age- age of the company; $P P C B$ - the predicted value of political connection. DID-the interaction between Treatment and Post-election. Treatment-It is a dummy variable equal to 1 for PDP connected firms and 0 for non-politically connected firms (in the case of column 5, Treatment is equal to 0 for APC connected firms). Post-election-It is a dummy variable equal to 1 for post-election (2015-2018) and 0 for years 2011-2014. Political-Proportion of directors who are affiliated with a political party. Political*PIP_interaction term between political connection and companies connected with party in power (PIP). Political*OPP-interaction term between political connection and companies connected with opposition party (OPP). Board tribe is measured as the proportion of board members that share the same tribe with the President. $t$-Statistics are shown in parentheses. $* * *, * *$, and $*$ denote statistical significance at the $1 \%, 5 \%$, and $10 \%$ level, respectively 
likely to be influenced by industry trends. Hence, we included the percentage of politically connected persons in the industry (INRatio) as a determinant in the first stage. We used the predicted variable (Predicted Pol) of the Political in the first stage as an instrumental variable to estimate the value of political connections. As presented in Table 8, the results of the 2SLS estimations in Column (2) are significant and similar to the results in the baseline model of Table 6. The coefficient of the predicted variable (Predicted Pol.) is 0.012 and is significant at $1 \%$. The results indicate that our findings are robust to potential endogeneity issues that might emerge from omitted variable bias and reverse causality.

Second, as politically connected persons are persons who have power as well as a relevant network of resources, they are likely to choose to serve on better-performing firms. This creates self-selection bias and simultaneity issues where the dependent variables are simultaneously determined by the dependent variable (Wooldridge 2010). Thus, following prior studies, we adopted the system Generalized Method of Movement (GMM) (Wintoki et al. 2012; Ahmed et al. 2017) to address potential issues of simultaneity and reverse causality. The results reported in Column (3) of Table 8 are consistent with the main findings of a significant and positive impact of political connections on firm performance, indicating that the findings appear robust to possible simultaneity and reverse causality issues.

Next, we follow Wei et al. (2020) to employ the difference in difference (DID) estimation to test the robustness of our findings of how a change in government affects the relation between political connections and firm performance. Our sample period, which covers the election year in 2015 and two different governments, allows us to use DID. DID is a widely used technique for examining the consequences of an event or policy change on an established relationship (Fang et al. 2014; Ahmed et al. 2017; Brogaard et al. 2017). Brogaard et al. (2017) suggest that the DID estimation helps to reduce the impact of omitted variables and biases driven by the sample period. Following prior studies (Ahmed et al. 2017; Bogaard et al. 2017), we created a variable Post-election with a value equal to 1 for years 2015-2018 and 0 for years 2011-2014 (the election was held in the early part of 2015, so we counted 2015 as the post-election year). We are interested in the performance of firms when their patron party loses power, so we designated firms connected to PDP ${ }^{3}$ as the treatment group. We test the treatment group against control groups, namely nonpolitically connected firms and APC connected firms, in two different regression models. Treatment group is equal to 1 for PDP firms and 0 for non-connected firms (or APC firms in Column 5 of Table 8). DID is an interaction between Treatment and Post-election. The statistically significant and negative coefficient of -0.89 for DID in Column (4) of Table 8 indicates that firms connected to a political party decrease performance after their patron party loses power compared with non-politically connected firms. Similarly, in Column (5) of Table 8, the significant negative coefficient of DID implies that firms connected to the opposition party experience a large drop in performance compared with firms connected to the incumbent party. The results from DID confirm our findings that politically connected firms are likely to underperform when their patron party falls from power.

Finally, given that CEO tribal connections with the President can affect the consequences of any political connections, it is plausible that board members' tribal connections could also influence our findings. Therefore, in columns 6-7 of Table 8, we control for board members' tribal connections to mitigate any potential effect of omitted variable bias.

3 PDP lost power in the 2015 election and became the major opposition party. 
Table 9 Financial and non-financial firms

\begin{tabular}{|c|c|c|c|c|c|c|c|c|}
\hline \multirow{4}{*}{ Variable } & \multicolumn{4}{|c|}{ Financial firms } & \multicolumn{4}{|c|}{ Non-Financial firms } \\
\hline & \multicolumn{2}{|c|}{ 2011-2014 PDP term } & \multicolumn{2}{|c|}{ 2015-2018 APC term } & \multicolumn{2}{|c|}{ 2011-2014PDP term } & \multicolumn{2}{|c|}{ 2015-2018APC term } \\
\hline & PIP & OPP & PIP & OPP & PIP & OPP & PIP & OPP \\
\hline & (1) & (2) & (3) & (4) & (5) & (6) & (7) & (8) \\
\hline Political & $\begin{array}{l}0.132 \text { *** } \\
(4.12)\end{array}$ & $\begin{array}{l}0.096^{*} \\
(1.74)\end{array}$ & $\begin{array}{l}0.076^{* * * *} \\
(6.54)\end{array}$ & $\begin{array}{l}0.009 \\
(1.57)\end{array}$ & $\begin{array}{l}0.076^{* * *} \\
(2.35)\end{array}$ & $\begin{array}{l}0.032^{*} \\
(1.71)\end{array}$ & $\begin{array}{l}0.052 * * * \\
(2.97)\end{array}$ & $\begin{array}{l}0.004 \\
(1.09)\end{array}$ \\
\hline Political*PIP & $\begin{array}{l}0.176^{* * * *} \\
(12.98)\end{array}$ & & $\begin{array}{l}0.134^{* *} \\
(2.31)\end{array}$ & & $\begin{array}{l}0.093 * * * \\
(4.81)\end{array}$ & & $\begin{array}{l}0.097 * * \\
(2.46)\end{array}$ & \\
\hline Political*OPP & & $\begin{array}{l}-0.237 * * \\
(-3.01)\end{array}$ & & $\begin{array}{l}-0.229 \text { *** } \\
(-7.87)\end{array}$ & & $\begin{array}{l}-0.026^{*} \\
(-1.87)\end{array}$ & & $\begin{array}{l}-0.019 * * \\
(-2.13)\end{array}$ \\
\hline Constant & $\begin{array}{l}0.115^{* *} \\
(2.13)\end{array}$ & $\begin{array}{l}0.141 * * \\
(2.33)\end{array}$ & $\begin{array}{l}0.103^{* * * *} \\
(3.29)\end{array}$ & $\begin{array}{l}0.153 * * \\
(2.27)\end{array}$ & $\begin{array}{l}0.190^{* * * *} \\
(4.41)\end{array}$ & $\begin{array}{l}0.183 * * * \\
(4.61)\end{array}$ & $\begin{array}{l}0.173 * * * \\
(4.37)\end{array}$ & $\begin{array}{l}0.186^{* * *} \\
(4.09)\end{array}$ \\
\hline Controls & Yes & Yes & Yes & Yes & Yes & Yes & Yes & Yes \\
\hline Industry effect & & & & & Yes & Yes & Yes & Yes \\
\hline Year effect & Yes & Yes & Yes & Yes & Yes & Yes & Yes & Yes \\
\hline Adj.R & 0.271 & 0.283 & 0.233 & 0.219 & 0.283 & 0.265 & 0.196 & 0.187 \\
\hline Observations & 196 & 196 & 196 & 196 & 380 & 380 & 380 & 380 \\
\hline
\end{tabular}

This table presents regression results for sub-samples of financial (highly regulated) and non-financial firms (less regulated). $P I P$-companies connected to the party in power. $O P P$-companies connected to the main opposition party. Political -Proportion of directors who are affiliated with a political party. Political $*$ PIPinteraction term between political connection and companies connected with party in power (PIP). Political $* O P P$-interaction term between political connection and companies connected with opposition party (OPP). $t$-Statistics are shown in parentheses. $* * *, * *$, and $*$ denote statistical significance at the $1 \%$, $5 \%$, and $10 \%$ level, respectively

The results remain the same as the main findings that the effects of political connections on firm value differs depending on whether the political party in government.

\subsection{Additional analyses and robustness tests}

\subsubsection{Financial versus non-Financial firms}

Brown and Huang (2017) argue that firms with more exposure to government regulations and policies are more likely to seek political access and hence expected to benefit more from political connections. Ferris et al. (2016) found that firms with political connections are more likely to avoid regulatory delays in acquisition and mergers. Therefore, we categorized our sample into highly regulated or financial firms (49 firms) and less-regulated firms or non-financial firms (95 firms). Financial firms include banks, insurances, and credit providers operating within the ambit of numerous laws and policies; others were classified as less regulated or non-financial firms.

The results in Table 9 show that political connections are more beneficial to financial firms, especially when their patron party is in power. However, the negative impact of political connections is non-trivial when financial firms are connected to the wrong party. This implies that the incumbent government does provide some regulatory relief for financial firms. In contrast, firms connected to the opposition party are likely to be challenged on regulations by the incumbent government. 
Table 10 Accounting for selection bias (unbalance panel data)

\begin{tabular}{|c|c|c|c|c|}
\hline \multirow[b]{2}{*}{ Variable } & \multicolumn{2}{|c|}{ 2011-2014 PDP term } & \multicolumn{2}{|c|}{ 2015-2018 APC term } \\
\hline & $\begin{array}{l}\text { PIP } \\
(1)\end{array}$ & $\begin{array}{l}\text { OPP } \\
(2)\end{array}$ & $\begin{array}{l}\text { PIP } \\
(3)\end{array}$ & $\begin{array}{l}\text { OPP } \\
(4)\end{array}$ \\
\hline Political & $\begin{array}{l}0.026^{* * * *} \\
(3.99)\end{array}$ & $\begin{array}{l}0.034^{*} \\
(1.67)\end{array}$ & $\begin{array}{l}0.032 * * * \\
(3.12)\end{array}$ & $\begin{array}{l}0.047 * \\
(1.79)\end{array}$ \\
\hline Political*PIP & $\begin{array}{l}0.195 * * * \\
(9.21)\end{array}$ & & $\begin{array}{l}0.155^{* * *} \\
(6.32)\end{array}$ & \\
\hline Political*OPP & & $\begin{array}{l}-0.053^{* *} \\
(-3.65)\end{array}$ & & $\begin{array}{l}-0.048^{* *} \\
(-2.93)\end{array}$ \\
\hline Constant & $\begin{array}{l}0.315^{* * * *} \\
(6.13)\end{array}$ & $\begin{array}{l}0.317 * * * \\
(6.73)\end{array}$ & $\begin{array}{l}0.296^{* * * *} \\
(8.27)\end{array}$ & $\begin{array}{l}0.299 * * * \\
(9.41)\end{array}$ \\
\hline Controls & Yes & Yes & Yes & Yes \\
\hline Industry effect & Yes & Yes & Yes & Yes \\
\hline Adj.R & 0.211 & 0.201 & 0.241 & 0.233 \\
\hline Observations & 611 & 611 & 473 & 473 \\
\hline
\end{tabular}

This table presents the regression results on the impact of political connection with the party in power and opposition party on firm performance using unbalanced panel data. $P I P$-companies connected to the party in power. $O P P$ - companies connected to the main opposition party. Political-Proportion of directors who are affiliated with a political party. Political $* P I P$-interaction term between political connection and companies connected with party in power (PIP). Political $* O P P$-interaction term between political connection and companies connected with opposition party (OPP). Total Assets-Total assets of the company measured in Billions of Nara. Sales growth-Proportionate change in sales from year to year. Leverage - total debt to total assets. Board size-Number of directors on the board. Non-executive-Number of non-executive directors on the board. $t$-Statistics are shown in parentheses. $* * *, * *$, and $*$ denote statistical significance at the $1 \%, 5 \%$, and $10 \%$ level, respectively

\subsubsection{Sample selection and survival bias}

Although balanced data has the advantage of mitigating attrition bias, it is likely to create sample selection and survival bias (Gujarati and Porter 2008; Wooldridge 2010). For instance, sample selection bias arises due to the specification of certain criteria for selecting the firms (Shehata 1991). Hence our selection of firms with full data over the 8 years could create sample selection bias. Also, the selection of only firms that existed throughout the 8 years eliminated firms that ceased operations or delisted, creating survival bias. Therefore, to address the issues of selection and survival bias, we perform an additional test that includes additional 18 firms not included in the initial balanced panel dataset. Those firms ceased operations and delisted or emerged at some point in the sample period. The results presented in Table 10 are not significantly different from the main results in Table 6, hence our results do not suffer from sample selection and survival bias.

\subsubsection{The effect of firm size and growth}

The descriptive statistics in Table 1 show that firms are likely to differ significantly in size (measured by total assets) and growth rate (measured by sale growth). We have mitigated 
Table 11 The effect of firm size and growth

Panel A-large vs. small firms

\begin{tabular}{|c|c|c|c|c|c|c|}
\hline \multirow{3}{*}{ Variable } & \multicolumn{3}{|c|}{ Large firms } & \multicolumn{3}{|c|}{ Small firms } \\
\hline & PIP & OPP & MUT & PIP & OPP & MUT \\
\hline & (1) & (2) & (3) & (4) & (5) & (6) \\
\hline political & $\begin{array}{l}0.056^{* * * *} \\
(4.05)\end{array}$ & $\begin{array}{l}0.053 * * \\
(2.51)\end{array}$ & $\begin{array}{l}0.028 * * \\
(2.02)\end{array}$ & $\begin{array}{l}0.026^{* * *} \\
(2.31)\end{array}$ & $\begin{array}{l}0.029 * * \\
(2.22)\end{array}$ & $\begin{array}{l}0.015^{*} \\
(1.67)\end{array}$ \\
\hline Political*PIP & $\begin{array}{l}0.143 * * * \\
(3.98)\end{array}$ & & & $\begin{array}{l}0.067 * * \\
(2.11)\end{array}$ & & \\
\hline Political*OPP & & $\begin{array}{l}-0.027^{* * * *} \\
(-3.65)\end{array}$ & & & $\begin{array}{l}-0.003^{*} \\
(-1.73)\end{array}$ & \\
\hline Political*MUT & & & $\begin{array}{l}0.017 * * \\
(2.47)\end{array}$ & & & $\begin{array}{l}0.001 \\
(1.51)\end{array}$ \\
\hline Constant & $\begin{array}{l}0.563 * * * \\
(11.23)\end{array}$ & $\begin{array}{l}0.634 * * * \\
(10.15)\end{array}$ & $\begin{array}{l}0.597 * * * \\
(11.18)\end{array}$ & $\begin{array}{l}0.474^{* * *} \\
(2.36)\end{array}$ & $\begin{array}{l}0.463^{* * *} \\
(2.28)\end{array}$ & $\begin{array}{l}0.421 \text { ** } \\
(2.41)\end{array}$ \\
\hline Controls & Yes & Yes & Yes & Yes & Yes & Yes \\
\hline Industry\&Year effect & Yes & Yes & Yes & Yes & Yes & Yes \\
\hline Adj. $R$ & 0.467 & 0.457 & 0.412 & 0.386 & 0.399 & 0.379 \\
\hline Observations & 544 & 544 & 544 & 608 & 608 & 608 \\
\hline
\end{tabular}

Panel B-high vs. low growth firms

\begin{tabular}{|c|c|c|c|c|c|c|}
\hline \multirow[b]{2}{*}{ Variable } & \multicolumn{3}{|c|}{ High growth firms } & \multicolumn{3}{|c|}{ Low growth firms } \\
\hline & $\begin{array}{l}\text { PIP } \\
(1)\end{array}$ & $\begin{array}{l}\text { OPP } \\
\text { (2) }\end{array}$ & $\begin{array}{l}\text { MUT } \\
\text { (3) }\end{array}$ & $\begin{array}{l}\text { PIP } \\
\text { (4) }\end{array}$ & $\begin{array}{l}\text { OPP } \\
(5)\end{array}$ & $\begin{array}{l}\text { MUT } \\
(6)\end{array}$ \\
\hline Political & $\begin{array}{l}0.038^{* * *} \\
(2.13)\end{array}$ & $\begin{array}{l}0.033 * * \\
(2.12)\end{array}$ & $\begin{array}{l}0.035 * * \\
(2.17)\end{array}$ & $\begin{array}{l}0.019 * * \\
(2.15)\end{array}$ & $\begin{array}{l}0.013^{* * *} \\
(2.19)\end{array}$ & $\begin{array}{l}0.018^{* * *} \\
(2.27)\end{array}$ \\
\hline Political*PIP & $\begin{array}{l}0.047 * * * \\
(3.11)\end{array}$ & & & $\begin{array}{l}0.039 * * \\
(2.38)\end{array}$ & & \\
\hline Political*OPP & & $\begin{array}{l}-0.005^{*} \\
(-1.81)\end{array}$ & & & $\begin{array}{l}-0.017 * * \\
(-2.16)\end{array}$ & \\
\hline Political*MUT & & & $\begin{array}{l}0.012 * * \\
(2.53)\end{array}$ & & & $\begin{array}{l}0.007 * \\
(1.77)\end{array}$ \\
\hline Constant & $\begin{array}{l}0.747 * * * \\
(8.63)\end{array}$ & $\begin{array}{l}0.765^{* * *} \\
(8.82)\end{array}$ & $\begin{array}{l}0.712 * * * \\
(8.41)\end{array}$ & $\begin{array}{l}0.814^{* * * *} \\
(9.89)\end{array}$ & $\begin{array}{l}0.809 * * * \\
(10.11)\end{array}$ & $\begin{array}{l}0.821 \text { *** } \\
(10.01)\end{array}$ \\
\hline Controls & Yes & Yes & Yes & Yes & Yes & Yes \\
\hline Industry \& year effect & Yes & Yes & Yes & Yes & Yes & Yes \\
\hline Adj. R & 0.347 & 0.342 & 0.351 & 0.401 & 0.423 & 0.407 \\
\hline Observations & 456 & 456 & 456 & 696 & 696 & 696 \\
\hline
\end{tabular}

This table presents the regression results on the impact of political connection with the party in power and opposition party on firm performance based on size and sales growth. Panel A contains results based on firm size. Large firms are firms with total assets above the mean assets value of the sample companies. Small firms are firms with total assets below the mean value of assets of the sample companies. High growth is firms with sales growth above the mean sales growth of the sample companies. Low growth is firms with sales growth below the mean sales growth of the sample companies. PIP-companies connected to the party in power. $O P P$ - companies connected to the main opposition party. Multiple-companies that have political connections with more than one political party. Political-Proportion of directors who are affiliated with a political party. Political ${ }^{*} P I P$-interaction term between political connection and companies connected with party in power (PIP). Political*OPP-interaction term between political connection and companies connected with opposition party (OPP). Political $* M U T$-interaction term between political 
Table 11 (continued)

connection and companies connected with multiple parties (MUT). t-Statistics are shown in parentheses. $* * *, * *$, and $*$ denote statistical significance at the $1 \%, 5 \%$, and $10 \%$ level, respectively

Table 12 The effect of switching or connecting with party in power

\begin{tabular}{llll}
\hline Variable & $\begin{array}{l}\text { Full sample period } \\
(1)\end{array}$ & $\begin{array}{l}2011-2014 \text { PDP term } \\
(2)\end{array}$ & $\begin{array}{l}\text { 2015-2018 APC term } \\
(3)\end{array}$ \\
\hline Political & $0.029^{* *}$ & $0.023^{* * *}$ & $0.021^{* * *}$ \\
& $(2.37)$ & $(2.68)$ & $(2.26)$ \\
Political*Switch & $0.034^{* *}$ & $0.031^{* *}$ & $0.026^{* *}$ \\
& $(2.06)$ & $(2.09)$ & $(2.01)$ \\
Switch & $0.018^{*}$ & $0.015^{*}$ & 0.016 \\
& $(1.83)$ & $(1.71)$ & $(1.63)$ \\
Constant & $0.509^{* * *}$ & $0.527^{* * *}$ & $0.513^{* * *}$ \\
& $(7.05)$ & $(6.90)$ & $(7.16)$ \\
Control & Yes & Yes & Yes \\
Industry effect & Yes & Yes & Yes \\
Year effect & Yes & Yes & Yes \\
Adj. R & 0.334 & 0.328 & 0.341 \\
Observations & 1152 & 576 & 576 \\
\hline
\end{tabular}

This table presents the regression results on the impact of switching political connections to a party in power or having a new connection with the party when in power. Political-Proportion of directors who are affiliated with a political party. Switch is binary variable equal to 1 for firms that switch to or connected with party in power or 0 otherwise. Political ${ }^{*}$ Switch is an interaction term between Political and Switch. $t$-Statistics are shown in parentheses. $* * *, * *$, and $*$ denote statistical significance at the $1 \%, 5 \%$, and $10 \%$ level, respectively

the effect of these factors on our results by including total assets and sale growth in the model. However, to further alleviate the concern of potential bias for bigger and faster growth firms, we perform an additional test using split sampling techniques. To do this, we separate the firms into large firms and small firms based on the average total assets value over the sample period. A firm is either classified as a large firm if its average total assets above the mean value of the full sample, or a small firm otherwise. Next, we run a separate regression for both large and small firms. The results are presented in Panel A of Table 11. In both groups, the results indicate that political connection has a differential impact on firm value depending on the status of the political party, and this confirms our main findings.

Regarding firm growth, we group firms based on average sales growth. A firm is classified as either high growth if its average sales growth is higher than mean sales growth or low growth otherwise. The results are presented in Panel B of Table 11. Similar to that of firm size, our results remain qualitatively similar to the main findings, suggesting that our results are not endogenous to firm size and growth. 


\subsubsection{A switch to or connection with party in power}

In this section, we test whether firms that switch to, or were connected with, a party when the party was in power enhance firm performance. To do this, we introduce a new variable, Switch, to capture firms that switch or connect with the party during their government term. Switch is a binary variable equal to either 1 for firms that switch or are connected with the party in power or 0 if otherwise. Those include firms that did not have a political connection with the party in power and begin appointing directors connected with the party in power. Next, we interact Switch with Political connection (Political*Switch), which becomes our variable of interest. The results are presented in Table 12. The positive and significant coefficient of the interaction term (Political*Switch) indicates that the parties that switch to or connect with the party in power experience increased firm performance. This result provides further confirmation to the main findings that political connections with the party in power is beneficial.

\section{Conclusion}

Prior studies show that political connections generally add value to firms. However, it is not clear whether political connections are still valuable in a highly partisan political environment, even when the affiliated political party is in opposition. To fill this gap in the literature, we examine the impact of political connections on firm value in a highly partisan political environment of Nigeria. We tested our hypotheses by sorting firms that are connected to two different political parties (PDP and APC) and analyze the value of these connections to firm performance over eight years of 2011-2018. Using both binary and proportionate measures of directors' political connections, our results are threefold. First, approximately $60 \%$ of listed firms have politically connected directors on their board, whether a former minister, member of parliament, national party office, or government appointee at the national level. Most of the firms were connected to either party in power or the main opposition party. Second, we find that political connections increased firm performance. However, our main analysis on the lines of the status of the political party reveals that political connections are more value relevant if the political party of the connected person is in government.

On the contrary, connections with the opposition are likely to reduce firm value. Thus, political connections in a partisan environment can be a good partnership at the wrong timing. Third, although it is generally perceived that tribalism hampers economic growth and success of a business, we find that firms can use tribal connections with the President to mitigate the negative impact of political connection when their patron party is in opposition. Specifically, a CEO tribal connection with the President has a significant positive impact on firm performance regardless of the company's political connection with any party.

Our study makes a number of new contributions to the existing literature as well as offers considerations for policy makers, regulatory authorities, and managers. First, this study is important in enhancing our understanding of the value relevance of political connections in a partisan political economy. It also gives compelling empirical evidence on the timing effect of political connection on firm performance. The evidence suggests that a politically connected person is useful when their political party is in power. However, 
having an opposition political party member on the board of directors is likely to reduce the firm's value, especially in a highly partisan political environment. Second, we provide empirical evidence that tribalism is likely to transcend the boundaries of political party affiliation; thus, the ethnic similarity between firm and government is still relevant because firms can offset the downside of opposition party connection if their CEO has a tribal connection with the President. Finally, our findings also indicate that for a stable political connection that yields a continuous positive value, a company must have people from different political parties because it reduces the stereotyping behavior of the public towards partisan politicians.

Although the current study focused on Nigeria, the findings are applicable to other countries where tribalism dominate politics and partisan politics is important in business relationships. Most developing countries and Africa, in particular, bear these characteristics, hence these results are applicable. For example, in the case of Ghana, the two dominating parties are built along tribal lines. The NPP is perceived to be Asantes, while the NDC is known to be Eves and Northerns. A similar pattern is noticeable in Kenya, Rwanda, etc. In Asia, Collins (2004) demonstrates the significance of tribal connection in many countries' political environments. Tribal connections are deeply intertwined with political relations in many middle eastern countries such as Iraq, Jordan, and Yemen (International Development Research Centre 2010). And the political connection is an essential ingredient for business operations. Therefore, our findings are applicable beyond the borders of Africa to many other developing countries. In summary, our findings apply to most countries where tribalism and partisan politics play an important role in the business environment. By extension, we argue that some form of connections with the President other than the political tie help a firm mitigate the negative effect of having a political tie with the opposition party.

Despite the wide use of binary and proportionate measures of political connections in political science, finance, and accounting literature, these measures do not take into account the level of access that each politically connected person has with the government. Therefore, future studies can investigate how connections with politicians at different levels affect performance.

Open Access This article is licensed under a Creative Commons Attribution 4.0 International License, which permits use, sharing, adaptation, distribution and reproduction in any medium or format, as long as you give appropriate credit to the original author(s) and the source, provide a link to the Creative Commons licence, and indicate if changes were made. The images or other third party material in this article are included in the article's Creative Commons licence, unless indicated otherwise in a credit line to the material. If material is not included in the article's Creative Commons licence and your intended use is not permitted by statutory regulation or exceeds the permitted use, you will need to obtain permission directly from the copyright holder. To view a copy of this licence, visit http://creativecommons.org/licenses/by/4.0/.

\section{References}

ADB, 'Nigeria Economic Outlook.' https://www.afdb.org/en/countries-west-africa-nigeria/nigeria-econo mic-outlook. Accessed 23 Mar 2019

Adesunkanmi OS (2014) Opinion: the impact of politics on businesses in Nigeria. https://thewillnigeria. com/news/opinion-the-impact-of-politics-on-businesses-in-nigeria/. Accessed 05 May 2019

Adhikari BK, Agrawal A (2016) Does local religiosity matter for bank risk-taking? J Corpor Financ $38: 272-293$ 
Adhikari A, Derashid C, Zhang H (2006) Public policy, political connections, and effective tax rates: Longitudinal evidence from Malaysia. J Account Public Policy 25(5):574-595

Agha E (2017) Nigeria: termination of expatriate quota- 16 companies threaten to pull out of Onne. https:// allafrica.com/stories/201711200037.html. Accessed May 2019

Agrawal A, Charles K (2001) Do some outside directors play a political role? J Law Econ 44(1):179-198

Ahmed A, Momen R, Ng C, Delaney D (2017) Gender diversity in corporate boards and continuous disclosure: evidence from Australia. J Contemp Account Econ 13:89-107

Ang J, Ding D, Thong T (2013) Political connection and firm value. Asian Dev Rev 30:131-166

Ang JS, Ding D (2006) Government ownership and the performance of government linked companies: the case of singapore. J Multinatl Financ Manag 16:64-88

Asongu SA, Nwachukwu JC (2018) Educational quality thresholds in the diffusion of knowledge with mobile phones for inclusive human development in sub-Saharan Africa. Technol Forecast Soc Chang 129:164-172

Balewa BAT (1994) Governing Nigeria-history, problems and prospects. Malthouse Press Ltd, Lagos

Baltagi BH (1998) Panel data methods in A. Ullah and D. E. A. Giles (eds) Handbook of Applied Economics Statistics (New York: Marcel Dekker), 291-324

Balsam S, Kwack SY, Lee JY (2017) Network connections, CEO compensation and involuntary turnover: the impact of a friend of a friend. J Corp Finan 45:220-244

Banerji S, Duygun M, Shaban M (2018) Political connections, bailout in financial markets, and firm value. J Corp Finan 50:388-401

Barney JB (1991) Firm resources and sustained competitive advantage. J Manag 17:99-120

Bawn K, Cohen M, Karol D, Masket S (2012) A theory of political parties: groups, policy demands, and nominations in American politics. Perspect Polit 10(3):571-597

Belghitar Y, Clark E, Saeed A (2019) Political connections and corporate financial decision making. Rev Quant Financ Acc 53:1099-1133

Bertrand M, Kramarz F, Schoar A, Thesmar D (2018) The cost of political connections. Rev Financ 22(3):849-876

Bianchi T, Viana RC, Castelo BM (2013) Corporate political connections. In: Idowu SO, Capaldi N, Zu L, Gupta AD (eds) Encyclopedia of corporate social responsibility. Springer, pp 520-525

Bloomberg (2018) Nigeria's Dangote Named As Buhari Election Campaign Adviser. Bloomberg.Com. https://www.bloomberg.com/news/articles/2018-1228/nigeria-s-dangote-named-as-buhari-electioncampaign-adviser

Bona-Sánchez C, Pérez-Alemán J, Santana-Martín DJ (2014) Politically connected firms and earnings informativeness in the controlling versus minority shareholders' context: European evidence. Corp Govern Int Rev 22(4):330-346

Bonardi JP, Urbiztondo S (2013) Asset freezing, corporate political resources, and the Tullock paradox. Bus Polit 15(13):275-293

Boubakri N, Guedhami O, Mishra D, Saffar W (2012) Political connections and the cost of equity capital. J Corp Financ 18(3):541-559

Boubakri N, Cosset JC, Saffar W (2008) Political connections of newly privatized firms. J Corp Finan 14(5):654-673

Breusch TS, Pagan AR (1980) The Lagrange multiplier test and its applications to model specification in econometrics. Rev Econ Stud 47:239-253

Brockman P, Rui OM, Zou H (2013) Institutions and the performance of politically connected M\&As. J Int Bus Stud 44(8):833-852

Brogaard J, Li D, Xia Y (2017) Stock liquidity and default risk. J Financ Econ 124:486-502

Brown J, Huang J (2017) All the President's friends: Political access and firm value. NBER Working Paper No. 23356. https://www.nber.org/papers/w23356.pdf (January, 2020)

Channel TV (2018) Presidency Lists Buhari's achievements after three years in office. https:// www.channelstv.com/2018/06/01/presidency-lists-buharis-achievements-in-security-econo my-others-after-three-years/

Chen CR, Li Y, Luo D, Zhang T (2017) Helping hands or grabbing hands? An analysis of political connections and firm value. J Bank Financ 80:71-89

Chen G, Firth M, Xu LP (2009) Does the type of ownership control matter? Evidence from China's listed companies. J Bank Financ 33(1):171-181

Channey P, Faccio M, Parsley D (2011) The quality of accounting information in politically connected firms. J Account Econ 52(1-2):58-76

Collins K (2004) The logic of clan politics: evidence from the Central Asian trajectories. World Polit 56(2):224-261 
Deloitte (2014) The Deloitte consumer review; Africa, 21st-century view. https://www2.deloitte.com/conte $\mathrm{nt} /$ dam/Deloitte/ng/Documents/consumer-business/the-deloitte-consumer-review-africa-a-21st-centu ry-view.pdf. Accessed 15 Febr 2019

Downs A (1957) An economic theory of democracy. Harper and row, New York

Ezeani E, Agudiegwu MO (2015) Partisan politics in multi-ethnic Nigeria: democracy for national disintegration. Res Human Soc Sci 5(22):53-63

Faccio M (2006) Politically connected firms. Am Econ Rev 96:369-386

Faccio M, Masulis R, McConnel J (2006) Political connections and corporate bailouts. J Financ 61:2597-2635

Fang VW, Tian X, Tice S (2014) Does stock liquidity enhance or impede firm innovation? J Financ 69:2085-2125

Ferguson T, Hans-Joachim V (2008) Betting on hitler-the value of political connections in Nazi Germany. Quart J Econ 123:101-137

Ferris S, Houston R, Javakhadze D (2016) Friends in the right places: the effect of political connections on corporate merger activity. J Corp Finan 41:81-102

Fisman R (2001) Estimating the value of political connections. Am Econ Rev 91:1092-1102

Fracassi C, Tate G (2012) External networking and internal firm governance. J Financ 67(1):153-194

Fuzi S, AbdulHalim A, Julizaerma K (2015) Board Independence and firm performance. Procedia Econ Financ 37:460-465

Goldman EJ, Rocholl A, So J (2008) Political connections and the allocation of procurement contracts. Working Paper, Indiana University

Gross C, Königsgruber R, Pantzalis C, Perotti P (2016) The financial reporting consequences of proximity to political power. J Account Public Policy 35(6):609-634

Guest P (2009) The impact of board size on firm performance: evidence from the U.K. Eur J Financ 15:385-404

Gbenga AM (2019) Dangote, five other companies to fund major road construction in Nigeria.https://ventu resafrica.com/dangote-five-other-companies-to-fund-major-roads-construction-in-nigeria/. Accessed 10 March 2019

Gujarati DN, Porter DC (2008) Basic econometrics, 5th edition. McGraw-Hill Education

Guo H, Xu E, Jacobs M (2014) Managerial, political ties, and firm performance during institutional transitions: an analysis of mediating mechanisms. J Bus Res 67(2):116-127

Gyapong E, Monem RM, Hu F (2016) Do women and ethnic minority directors influence firm value? Evidence from post-apartheid South Africa. J Bus Financ Acc 43(3-4):370-413

Halford J, Li C (2019) Political connections and debt restructuring. J Corp Financ 65:101497 (in press)

Hansen W (2017) Boko haram: religious radicalism and insurrection in northern Nigeria. J Asian Afr Stud 52(4):551-569

Hausman JA (1978) Specification tests in econometrics. Econometrica 46(6):1251-1272

Hewstone M, Rubin M, Willis H (2002) Intergroup bias. Annu Rev Psychol 53:575-604

Hill M, Fuller K, Kelly W, Washam J (2014) Corporate cash holdings and political connections. Rev Quant Financ Acc 42:123-142

Hillman AJ, Dalziel T (2003) Boards of directors and firm performance: integrating agency and resource dependence perspectives. Acad Manag Rev 28(3):383-396

Hillman AJ, Withers MC, Collins BJ (2009) Resource dependence theory: a review. J Manag 35(6):1404-1427

International Development Research Centre (2010) Political Role of Tribes: Analysis of Tribalism, Islamism, and Gender in Iraq, Jordan, and Yemen. IDRC - International Development Research Centre. https://www.idrc.ca/en/project/political-role-tribes-analysis-tribalism-islam ism-and-gender-iraq-jordan-and-yemen

Jensen MC (1988) Agency costs of free cash flow, corporate finance, and the market for takeovers. Am Econ Rev 76:323-329

Jin X, Chen Z, Luo D (2019) Anti-corruption, political connections, and corporate responses: evidence from Chinese listed companies. Pac-Basin Financ J 57:101198

Johnson S, Mitton T (2003) Cronyism and capital controls: evidence from Malaysia. J Financ Econ 67(2):351-382

Juma C (2012) Viewpoint: How tribalism stunts African democracy. BBC News. https://www.bbc.com/ news/world-africa-20465752

Katsina AM (2016) Peoples democratic party in the fourth Republic of Nigeria: nature, structure and ideology. SAGE Open 6(2):1-11

Khwaja I, Mian A (2005) Do lenders favor politically connected firms? Rent-seeking in an emerging financial market. Quart J Econ 120:1371-1411 
Idris H, Mudashir I, Olaniyi M (2018) 6 factor which rules 2019 elections, The Daily Trust (Abuja). Retrieved in May 2019

Ilyukhin E (2015) The impact of financial leverage on firm performance: evidence from Russia. J Corp Financ Res 9(2):24-36

INEC (2019) Kogi and Bayelsa States 2019 governorship elections countdown to Saturday, 2 November 2019, 08:00:00 (Lagos time). https://www.inecnigeria.org/elections/election-candidates/. Accessed 20 April 2019

Jackowicz K, Kozłowski L, Mielcarz P (2014) Political connections and operational performance of nonfinancial firms: new evidence from Poland. Emerg Mark Rev 20:109-135

Lee J, Blevins DE (1990) Profitability and sales growth in industrialized versus newly industrializing countries. MIR: Manag Int Rev 87-100

Leuz C, Oberholzer-Gee F (2006) Political relationships, global financing, and corporate transparency: Evidence from Indonesia. J Financ Econ 81(2):411-439

Omodia SM (2010) Political parties and party politics in the fourth Nigeria republic. Trakia J Sci 8(3):65-69

Liu Y, Wei Z, Xie F (2014) Do women directors improve firm performance in China? J Corp Finan 28:169-184

Maaloul A, Chakroun R, Yahyaoui S (2018) The effect of political connections on companies' performance and value: Evidence from Tunisian companies after the revolution. J Account Emerg Econ 8(2):185-204

McWilliams A, Van Fleet DD, Cory KD (2002) "Raising rivals"' costs through political strategy: an extension of resource-based theory." J Manag Stud 39(5):707-723

Mitchell H, Joseph S (2010) Changes in Malaysia: capital controls, prime ministers, and political connections. Pac Basin Financ J 18(5):460-476

Monem R (2013) Determinants of board structure: evidence from Australia. J Contemp Account Econ 9:33-49

Mwakikagile G (2001) Ethnic politics in Kenya and Nigeria, Abuja; Nova Publishers, NSE (2018). The Nigerian Stock Exchange. http://www.nse.com.ng/market-data/trading-statistics/equities. Accessed 09 Jan 2019

Ntim CG, Soobaroyen T (2013) Corporate governance and performance in socially responsible corporations: New empirical insights from a neo-institutional framework. Corpor Govern Int Rev 21:468-494

Osuma O, Ikelegbe A (2009) The people democratic party and governance in Nigeria, 199-2007. J Soc Sci 19(3):185-199

Owoeye F (2018) Tony Elumelu's Heirs Holdings may acquire Shell oil assets. Nairametric, Business News. https://nairametrics.com/2018/07/20/heirs-holdings-plc-set-to-acquire-shell-nigeria/

Park HM (2011) Practical guides to panel data modeling: a step-by-step analysis using Stata. Public management and policy analysis program, Graduate School of International Relations. International University of Japan, 1-52

Pascual-Fuster B, Crespí-Cladera R (2018) Politicians in the boardroom: is it aconvenient burden? Corpor Govern Int Rev 26(6):448-470

Pfeffer J, Salancik GR (1978) The external control of organizations: a resource dependence perspective. Harper, and Row, New York

Pham AV (2019) Political risk and cost of equity: The mediating role of political connections. J Corp Finan $56: 64-87$

PWC (2019) Nigeria economic outlook Top 10 themes for 2019. https://www.pwc.com/ng/en/assets/pdf/ nigeria-economic-outlook-2019.pdf

Sahara Reporter (2006) Baba's boys and their deals. http://saharareporters.com/2006/07/09/babas-boys-andtheir-dealsthenewssaharareporterscom

Schwarz W (1966) Tribalism and politics in Nigeria. World Today 22(11):460-467

Schweizer D, Walker T, Zhang A (2019) Cross-border acquisitions by Chinese enterprises: the benefits and disadvantages of political connections. J Corp Finan 57:63-85

Shehata M (1991) Self-selection bias and the economic consequences of accounting regulation: an application of two-stage switching regression to SFAS No. 2. Account Rev 66(4):768-787

Sepetro (2019) General TY Danjuma. http://www.sapetro.com/general-ty-danjuma/?cn-reloaded=1

Sharma P, Cheng LTW, Leung TY (2020) the impact of political connections on Chinese export firms' performance-lessons for other emerging markets. J Bus Res 106:24-34

Shin J, Hyun JH, Oh S, Yang H (2018) The effects of politically connected outside directors on firm performance: evidence from Korean chaebol firms. Corpor Gov Int Rev 26:23-44

Shleifer A, Robert V (1994) Politicians and firms. Quart J Econ 109:995-1025

Siegel J (2007) Contingent political capital and international alliances: evidence from South Korea. Adm Sci Q 52(4):621-666 
Sklar R (2004) Nigerian political parties: power in an emergent African nation. Publisher Africa World Press, California

Su ZQ, Fung GH, Huang DS, Shen CH (2014) Cash dividends, expropriation, and political connections: evidence from China. Int Rev Econ Financ 29:260-272

Tajfel H, Turner JC, Austin WG, Worchel S (1979) An integrative theory of intergroup conflict. Org Ident Read 56:65

Tajfel H (1982) Social identity and intergroup relations. Cambridge University Press, Cambridge UK

Tawiah V, Karungi V (2020) Differences in political orientation and foreign aid utilization in Africa. Dev Stud Res 7(1):119-130

The Africa Report (2015) Nigeria: The men behind the money. The Africa Report.Com. https://www.theaf ricareport.com/3357/nigeria-the-men-behind-the-money/

Tu G, Lin B, Liu F (2013) Political connections and privatization: evidence from China. J Account Public Policy 36(2):114-135

Transparency International (2019) https://www.transparency.org/cpi2018. Accessed 25 March 2019

Ujo AA (2001) Understanding party politics in Benue State. Anyaotu Enterprises and Publishers Nigeria Ltd, Nigeria, Kaduna

U.S. News and World Report (2018) Best countries 2018 global rankings, international news, and data insight. https://www.usnews.com/news/best-countries/open-for-business-rankings

VON (2019) Dangote Group begins installation of Rice factory in Kebbi. https://www.von.gov.ng/dangotegroup-begins-installation-of-rice-factory-in-kebbi/

Wang Z, Chen MH, Chin C, Zheng Q (2017) Managerial ability, political connections, and fraudulent financial reporting in China. J Account Public Policy 36(2):141-162

Wang Y, Abbasi K, Babajide B, Yekini KC (2019) Corporate governance mechanisms and firm performance: evidence from the emerging market following the revised CG code. Corp Governance 20:158-174

Wei C, Hu S, Chen F (2020) Do political connection disruptions increase labor costs in a governmentdominated market? Evidence from publicly listed companies in China. J Corpor Financ 62:101554

Wintoki MB, Linck JS, Netter JM (2012) Endogeneity and the dynamics of internal corporate governance. J Financ Econ 105:581-606

Wong W, Hooy C (2018) Do the types of political connections affect firm performance differently? Pac Basin Financ J 51:297-317

Wooldridge JM (2010) Econometric analysis of cross-section and panel data. MIT Press, Cambridge

Wu H, Li S, Ying SX, Chen X (2018) Politically connected CEOs, firm performance, and CEO pay. J Bus Res 91:169-180

Wu W, Wu C, Rui OM (2012a) Ownership and the value of political connections: evidence from China. Eur Financ Manag 18(4):695-729

Wu W, Wu C, Zhou C, Wu J (2012b) Political connections, tax benefits, and firm performance: evidence from China. J Account Public Policy 31(3):277-300

Yang D, Lu Z, Luo D (2014) Political connections, media monitoring, and long-term loans. China J Account Res 7(3):165-177

Zoogah DB (2016) Tribal diversity, human resources management practices, and firm performance. Can J Adm Sci 33(3):182-196

Publisher's Note Springer Nature remains neutral with regard to jurisdictional claims in published maps and institutional affiliations. 